\title{
Research Paper \\ The Effect of Acceptance and Commitment Therapy (ACT) on Increasing the Self-Compassion, Distress Tolerance, and Emotion Regulation in Students with Social Anxiety Disorder
}

Romina Roohi ${ }^{1}$, Aman Allah Soltani ${ }^{* 2}$, Zahra Zinedine Meimand ${ }^{2}$, Vida Razavi Nematollahi ${ }^{2}$

1. Ph.D. in Educational Psychology, Kerman Branch, Islamic Azad University, Kerman, Iran 2. Assistant Professor, Department of Psychology, Kerman Branch, Islamic Azad University, Kerman, Iran

Citation: Roohi R, Soltani AA, Zinedine Meimand Z, Razavi Nematollahi V. The effect of acceptance and commitment therapy (act) on increasing the self-compassion, distress tolerance, and emotion regulation in students with social anxiety disorder. Quarterly Journal of Child Mental Health. 2019; 6(3): 173-187.

http://dx.doi.org/10.29252/jcmh.6.3.16

\section{A R T I C L E I N F O}

\section{Keywords: \\ Commitment and acceptance, self-compassion, distress tolerance, emotion regulation}

Received: 04 Mar 2018

Accepted: 16 Jul 2018

Available: 9 Nov 2019

\section{A B S T R A C T}

Background and Purpose: Social anxiety is one of the most debilitating anxiety disorders that cause incompatibility in personal life, social interactions, and professional. This study was to investigate the effect of acceptance and commitment therapy on increasing self-compassion, distress tolerance, and emotion regulation in students with social anxiety disorder.

Methods: This study was a semi-experimental research with pretest-posttest control group design. The statistical population included all female secondary school students with social anxiety disorder in Tehran in 2016, among them 60 were selected and randomly divided into the experimental and control groups (30 per group). Social anxiety questionnaire (Connor et al., 2000), self-compassion scale (Norbala, 2013), distress tolerance scale (Simon et al., 2005), and emotion regulation scale (Garnfex et al., 2001) were used to gather the data. The experimental group underwent 8 sessions of commitment and acceptance therapy. Finally, the data were analyzed by univariate and multivariate analysis of covariance.

Results: Results of the study showed that commitment and acceptance therapy had a significant effect on reducing the social anxiety and increasing the self-compassion, distress tolerance, and emotion regulation of the students. Also, results of covariance analysis showed that commitment and acceptance therapy had a significant effect on reducing social anxiety $(F=288.817, \eta=0.535, p$ $<0.05)$ and increasing the total self-compassion $(F=149.196, \eta=0.62 \quad p<0.05)$, distress tolerance $(F$ $=352.88, \eta=0.56, \mathrm{p}<0.05)$ and emotion regulation $(\mathrm{F}=185.842, \eta=0.57, \mathrm{p}<0.05)$.

Conclusion: Based on the findings of this research, it can be concluded that by acceptance and commitment therapy, the students are taught to deal with the social anxiety through increasing the mental and subjective acceptance of the inner experiences rather than mentally avoiding the social thoughts and situations. Also, active and effective confrontation with the thoughts and feelings, changing attitudes to self, and review of life values and objectives are among the main effective factors of acceptance and commitment therapy.

\footnotetext{
* Corresponding author: Aman Allah Soltani, Assistant Professor, Department of Psychology, Kerman Branch, Islamic Azad University, Kerman, Iran.

E-mail addresses: Soltanimani@yahoo.com
} 


\section{تأثير درمان مبتنى بر يذيرش و تعهد بر افزايش شفقت به خود، تحمل بريشانى، و تنظيم هيجان در

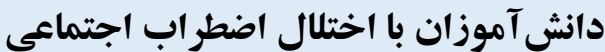

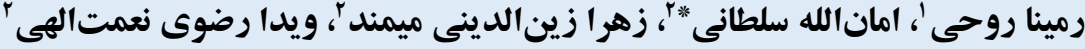

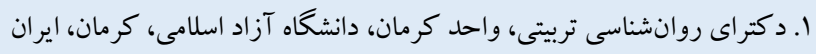

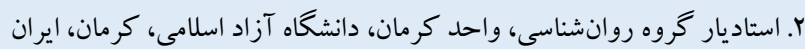

\section{جكيله}

زمينه و هدف: اضطر اب اجتماعى يكى از ناتوان كننده ترين اختلالات اضطر ابى است كه در زندگى شخصى، تعاملات اجتماعى، زندگى

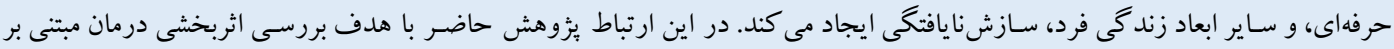
يذيرش و تعهد بر افزايش شفقت به خود، تحمل يريشانى، و تنظيم هيجان در دانش آموزان با اختلال اضطر اب ابت اجتماعى انجام شده است.

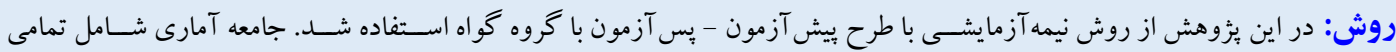

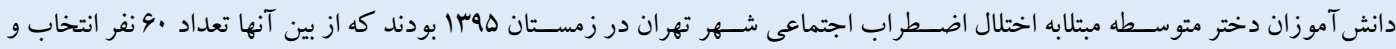

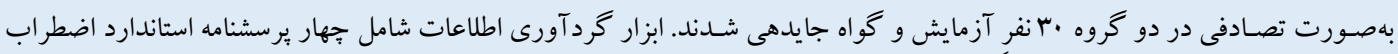

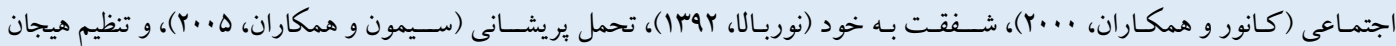

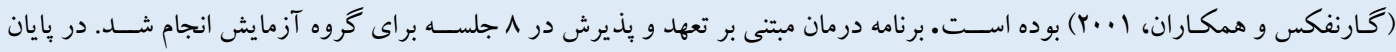

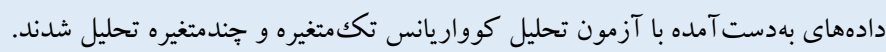
يافته ها: نتايج تحليل دادهها نشـان داد كه درمان مبتنى بر تعهد و يذيرش در كاهش اضطر اب اجتماعى و افزايش شـفقت به خود، افزايش

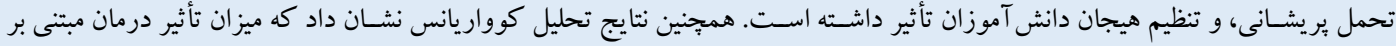

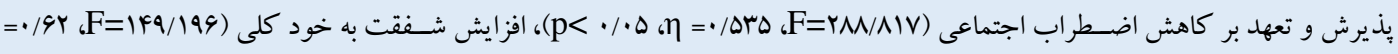
|

نتيجه كيرى: بر اسـاس يافتهاى حاصل از اين يزوهش مىتوان گفت در درمان مبتى بر يذيرش و تعهد به دانش آموزان آموخته مىشود

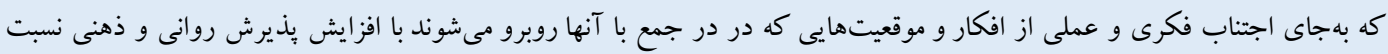

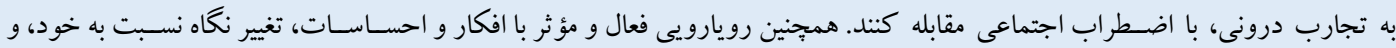

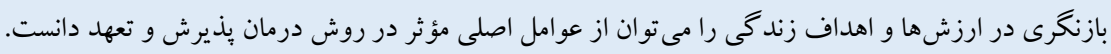

مشخصات مقاله

كليدوازهها:

تعهل و يذيرش،

شفقت به خود،

تحمل بريشانى،

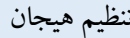

دريافت شده:

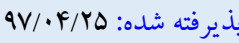

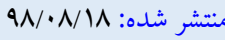

* نويسنده مسئول: امانالله سلطانى، استاديار گروه روانشناسى، واحد كرمان، دانشكاه آزاد اسلامى، كرمان، ايران.

Soltanimani@yahoo.com : راياناهة

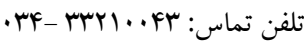


اولين مؤلفه شــناختى - رفتارى در ارتباط با اضــطر اب اجتماعى در يثزوهش حاضـر، توانمندى در شـفت و مهربانى با خود است . شفقت به خود در واقع حساسيت به رنج ديخران همراه با تعهد براى انجام دادن كارى درباره آن اسـت (A). بر اسـاس اين تعريف، اين متغير از سـه مؤلفه تشكيلشـده است: مهربانى با خودّدر مقابل قضاوت در مورد

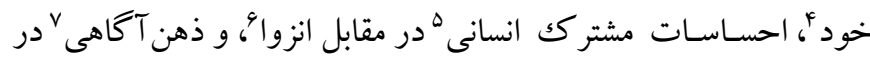
مقابل فزونهمانندسـازى ^كه تر كيب اين سـه مؤلفه مرتبط، مشـخصه فردى اسـت كه شفقت به خود در او وجود دارد. مفهوم خود شفقتى به معناى تجربه يذيرى و تحت تأثير قرار گرفتن از رنج ديگران تعريف شده اسـت، به كونهاى كه فرد مشـكلات و رنجهاى خود را قابل تحمل تر كند. اين مفهوم همجينين به معناى صـسبور و مهربان بودن نسـبت به ديخران و داشـتن دركك غير قضـاوت گر انه در رابطه با آنها اسـت (9). افرادى كه نمره بالايى در شـفقت بر خود، كسـب كردهاند نمره كمترى در روانرنجورخويى و اضسطراب؛ و نمره بالاترى در ميزان رضـايت از زندكى، بيوند اجتماعى، و سـلامت ذهنى كسـب مى كنند (· (1). افراد خود شـفتتورز درد و احسـاس نقص كمترى را نسبت به سايرين تجربه مى كنند و ديد كاه حمايت گر انهاى نســبت به خود دارند كه باعث كمتر شـدن احسـاس افسردكى و اضـطراب و افزايش رضايت آنها از زندكى مىشـود (1). تصـور بر اين اسـت كه اضطراب اجتماعى در واقع نوعى يريشـانى موقعيتى است و توانمندى فرد در تحمل اين يريشانى، قدرت او را براى مهار و كاهش آن افزايش مىدهد. كاهش سطح تحمل ير يشانى ممكن است با پاسخ هاى سازشنايافته نسبت به تنش، و اضطراب ناشى از بـهـ دنبال فرصـت بودن براى فرار از عاطفه منفى يا اجتناب از آن، همراه

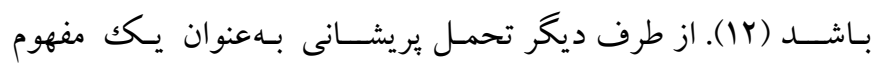
فراهيجانى ج در دانش آموزان با اضطر اب اجتماعى بالا مفهومسـازى شده اسـت و بهعنوان يكك صـفت هيجانى در نظر كرفته مىشود. اين رفتار، ״اسـخ عاطفى سـودمندى است كه بهعنوان تو انايى شخص براى تحمل حالات درونى ناخوشـايند تعريف شــده اســت (rا). مطابق ديدكاه سـيمونز و كاهر (IF) افراد داراى تحمل بريشـانى پيايين به اين حقيقت

\section{Isolation}

7. Mindfulness

8. Over identification

9. Meta-emotion
مقامها

اختلال اضطراب اجتماعى' بهصورت امروزى نخستين بار با انتشار كتاب راهنماى تشـخيصسى و آمارى اختلال هاى روانى مطرح شــد ( (1). هرجند ماركس و كلدر (1994)، بر اي نخسـين بار نشـانكان فوبى اجتماعى را توصـــف كردنـد، اما اين تشــخيص بهعنوان يكك طبقه متمايز تا معرفى راهنماى تشخيصى و آمارى اختلال هاى روانى تا سال •191 شناخته نشد (Y). كود كانى كه مبتلابه اختلال اضـطراب اجتماعى هستند در مقايسه با ديخر نوجوانان با ترسى نشانهدار و مزمن (مداوم و مستمر) از يكك يا جند موقعيـت اجتمـاعى يـا عملكردى در مواجهـه بـا افرادى نـآشـــنا روبهرو مى شـــــــــ و در آن موقعيت هيجانات بســيار شـــديد و مزمنى را تجربه مى كنند. نشانه هاى خاص اضطراب بسيار مشكل ساز هستند، زيرا تغييرات فيزيولوزيكى خاصسى مانند لرزش، سـرخ شـدن، و يا عرق كردن در فرد

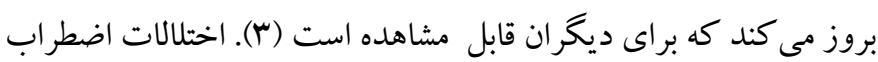
اجتماعى در سـن Iا سـالكى شـروع مى شـود و طول عمر آن ب در درصد اسـت. معمولاً هنگًامى كه اين اختلال درمان نشود به دورهاى درازمدت از ناتوانى مى انجامد و علائم اضـطر اب همجنان ادامه دارد و احتمالاً زندكى النى حرفهاى، تحصـيلى، و اجتماعى نوجوان را مختل مى كند (F). ئزوهش ها نشان دادهاند كه مؤلفههاى شناختى-رفتارى در اضطراب اجتماعى، نقش مهمى بـازى مى كنتـــ (ه). افر اد مبتلـابـه اضــــر اب اجتماعى وقتى كه در

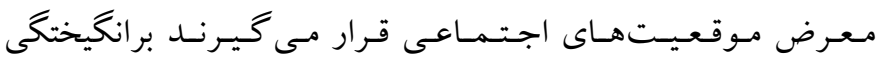
فيزيولوزيكى شــان افزايش مى يابد. اين افراد علائم جســمانى را بهعنوان نشــانـهاى از خطر يـا اضـــطراب تفســير مى كنتـد و جنين تفســيرى از بر انخيختخى فيزيولوزيكى، بـه افزايش علائم اضــطراب، مانند تيش قلب بيشـتر يا سـرخ شدن منجر مى شود و در نتيجه بر انكيختكى فيزيولوزيكى ممكن است نقش مهمى را در ايجاد ترس در موقعيتهاى اجتماعى بازى كنـد (9). ارزيـابى منفى از خود، هراس از ارزيـابى ديكران، اجتنـاب از موقعيتهاى ارزيابى، و ترس از اين كه ديكران از فرد ارزيابى منفى داشته باشـند، ازجمله بارزترين خصـايص شـناختى اضـطراب اجتماعى به شمار

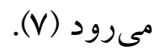

1. Social Anxiety Disorder (SAD)

2. Marx and Golder

3. Self- Kindness

4. Self- Judgment

5. Common humanity 
سـنين اوج اسـتقلال طلبى فرد بروز كرده و بهبود خود به خودى آن بسيار

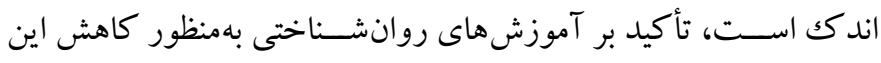
مشــكلات بين فردى و ارتباطى از اهميت زيادى برخوردار اســت. اخيراً

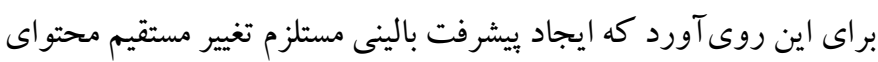

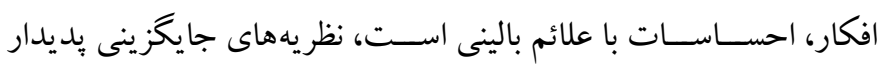

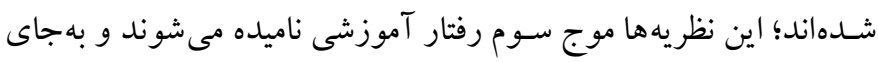
تغيير شكل، فراوانى يا حساسيت موقعيتى شناخت ها و هيجانات، كار كرد

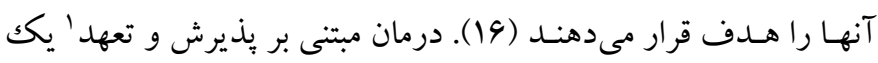

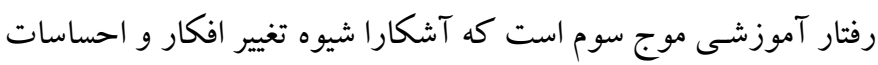

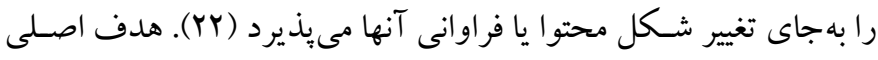
در اين نوع درمان ايجاد انعطاف يذيرى روانى اســت. در اين درمان ابتدا

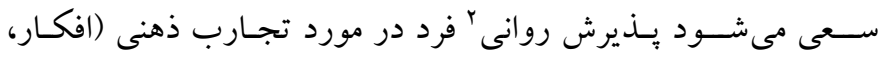

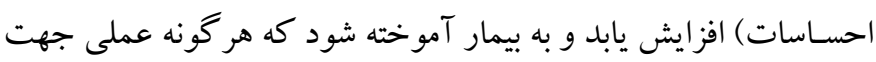

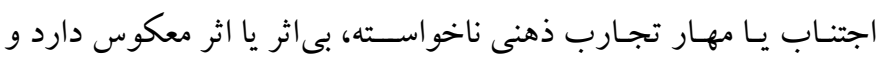

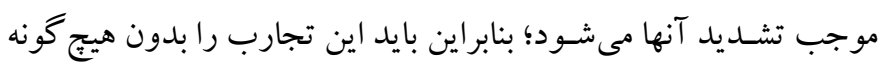

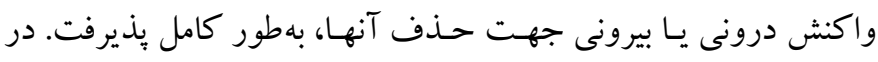

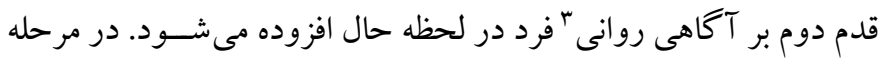

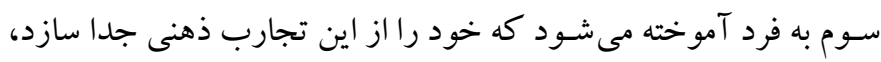

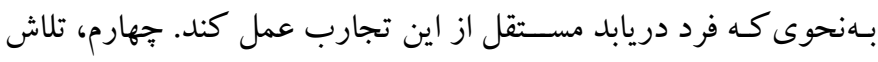

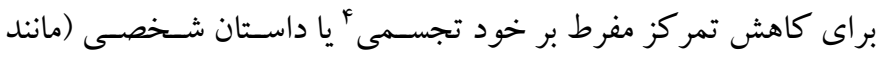

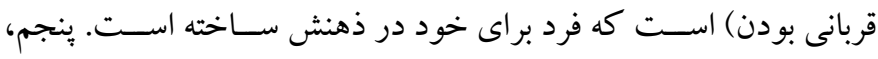
كمكك به فرد تا اينكه ارزش هاى شـخصى اصلى خود را بشناسد و بهطور

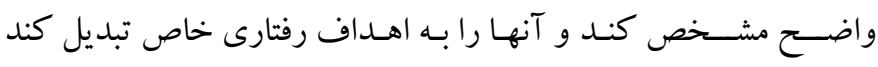

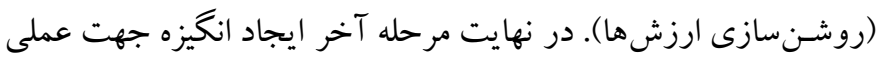

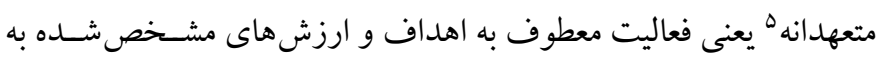

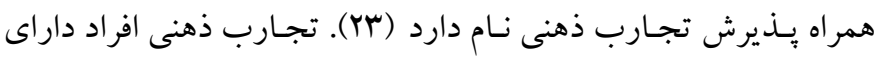

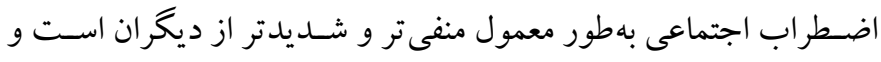

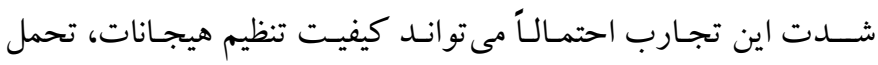

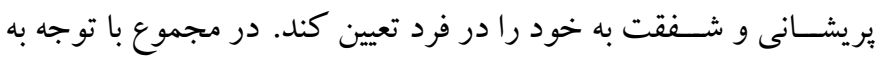

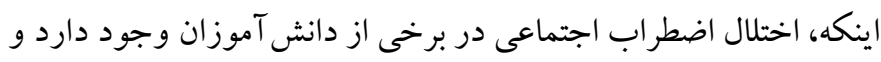

4.Cognitive Diffusion

5. Committed Action
واقف هستند كه نمى توانند احساس ناراحتى را تحمل كرده و احساس

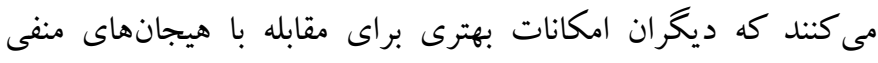

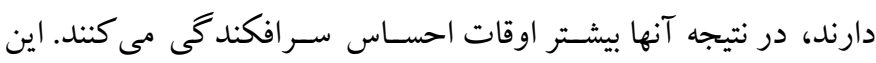

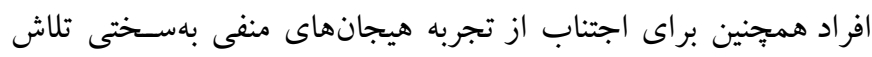

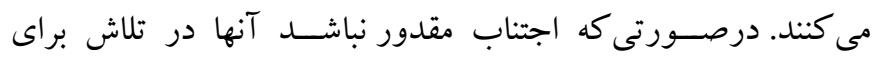
برطرف كردن حالت هيجانى آزارنده به روشهاى ناسـالمى روى

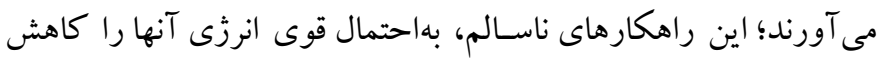

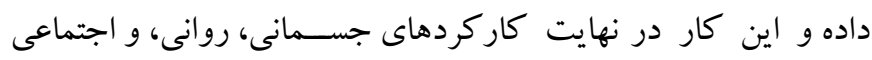

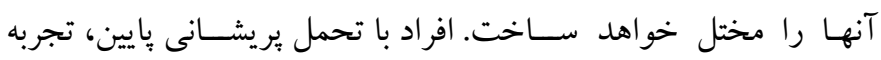
بريشانى هيجانى راغيرقابل تحمل توصيف مى كنند، بريشانى هيجانى را

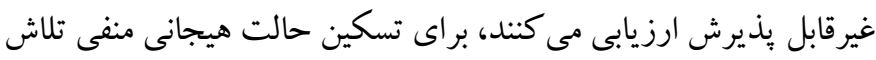

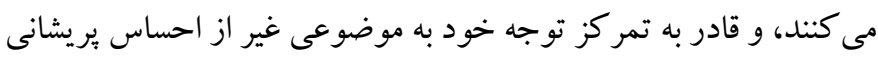
نيستند (ها و 19) - (19). شـواهد جديد درباره اختلالات اضطر ابى نشان مىدهد كه مشكل در

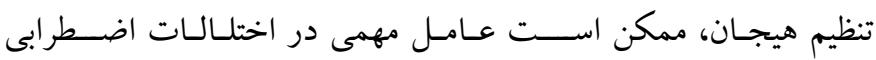
دانش آموزان باشــــ (IV). تنظيم هيجان فرايندى اســــ كه از طريق آن افر اد هيجانهاى خود را بهصسورت هوشسيار يا ناهوشسيار تعديل مى كنند

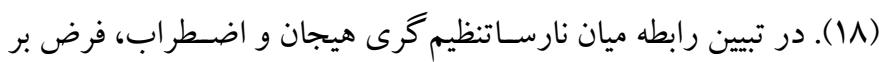

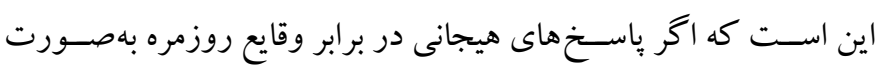

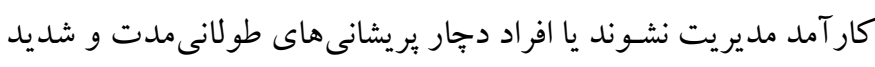

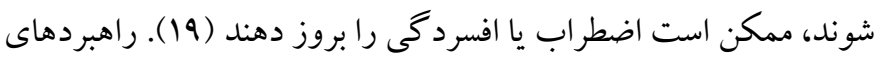

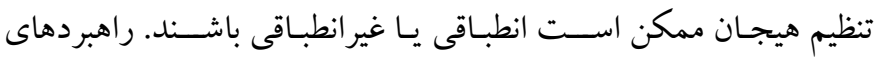

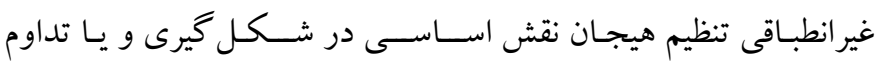

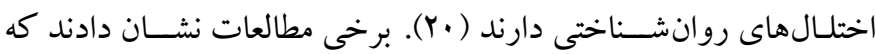
روش درمانى مبتنى بر تعهـد و يذيرش بر كاهش ميزان ســرزنش خوده،

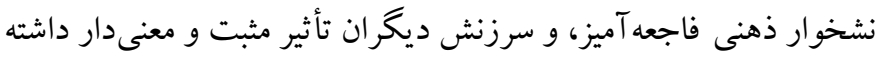

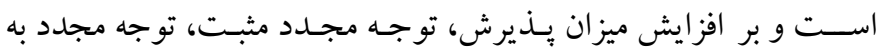

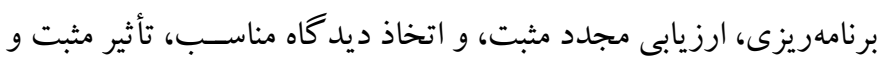

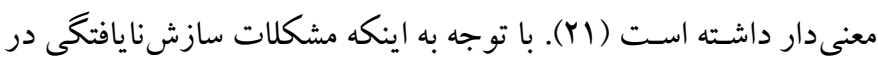

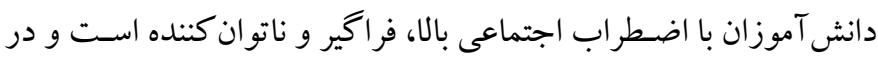

1. Acceptance \& Commitment Therapy

2. Psychological Acceptance

3. Psychological Awareness 


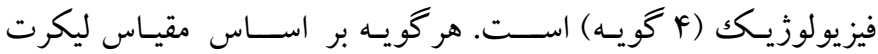
ينجدرجهاى سـنجش مى شـود. بر اساس يُزوهش سازنده اين ابزار، اعتبار

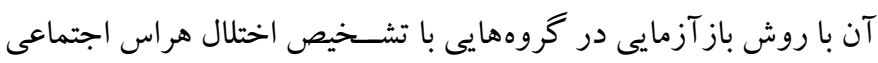

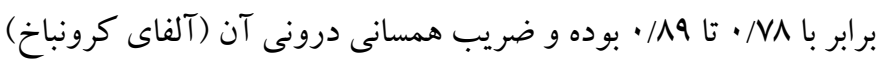

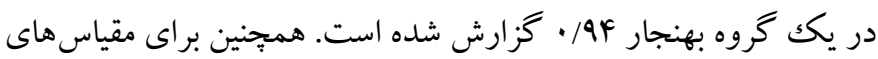

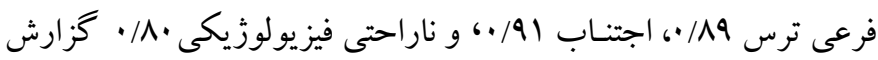

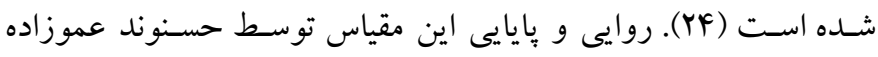

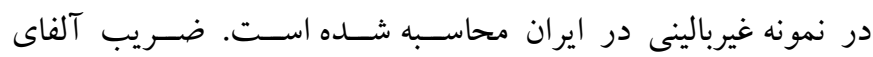

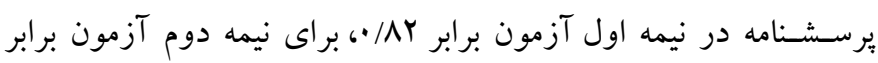

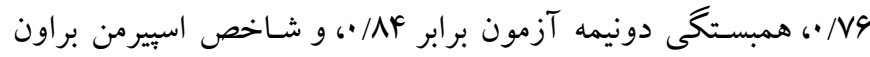

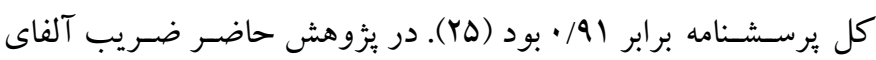
كرونباخ سN/ • به دست آمد. r) مقياس تحمل بريشانى r: مقياس تحمل بريشـانى كه بهوسيله سيمونز

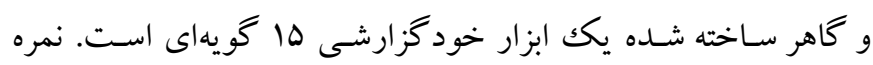

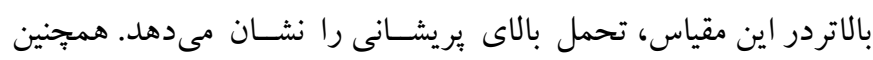

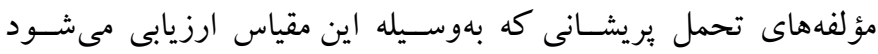

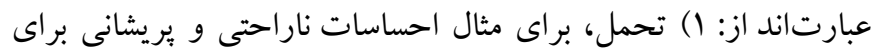

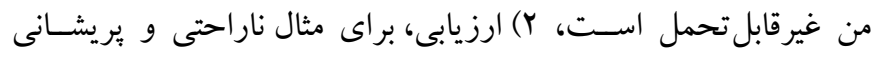

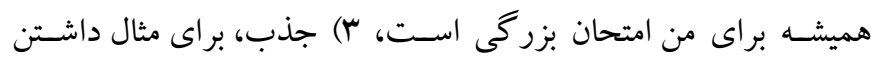

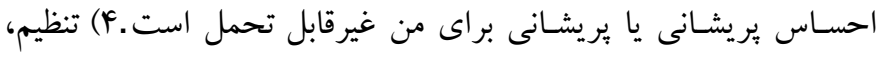

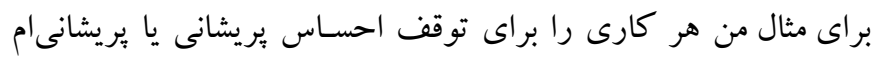

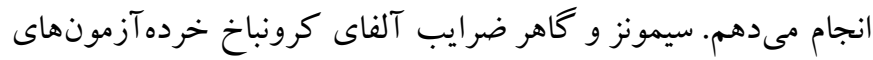

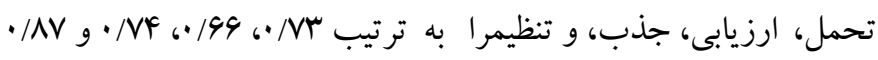

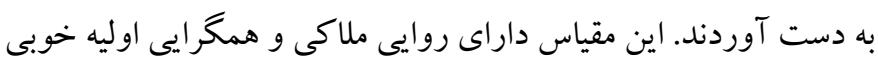

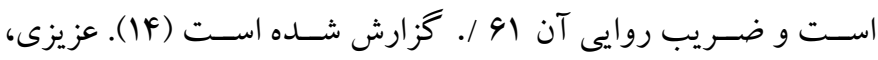

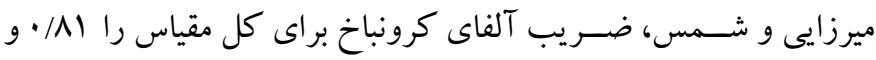

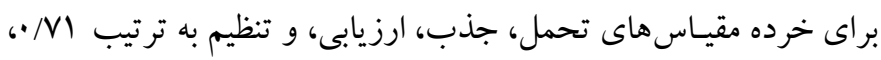

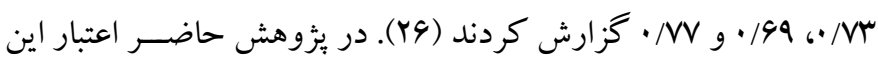

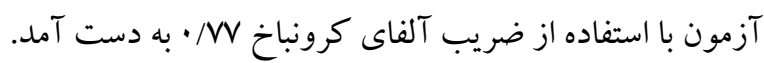

2 .Disturbance Tolerance Scale
تحمـل بريشــانى و افزايش شــقت به خود و تنظيم هيجان مى تواند در

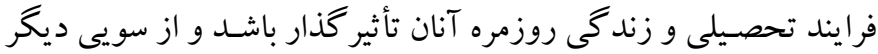

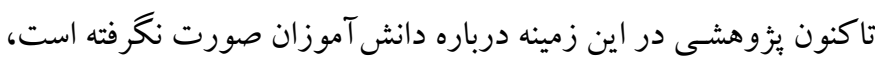

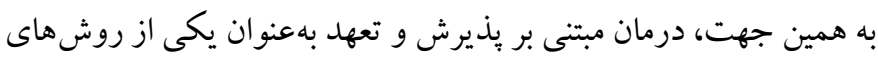

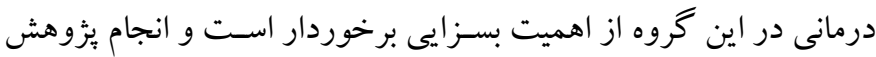

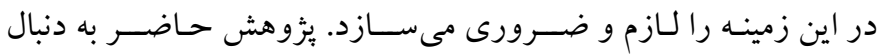

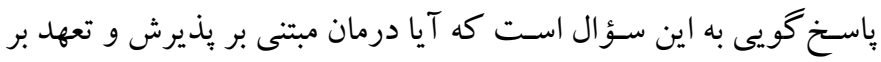

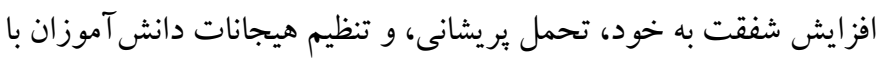

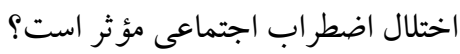

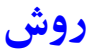
الف) طرح يزوهش و شر كت كنند كان: يزوهش حاضر يكك مطالعه از

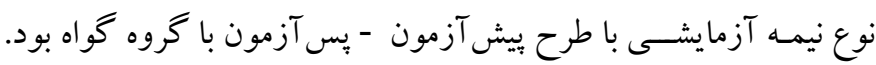

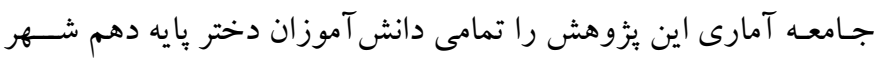
تهر ان در سـال هوץ| تشـكيل دادند كه توسط مشـاوران مدارس به دفتر

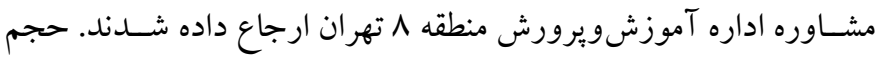

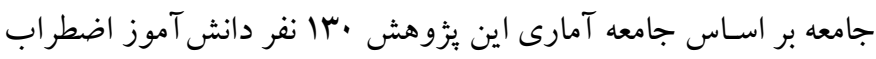

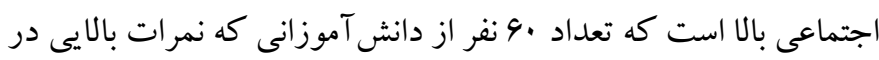
ير سـشـنامه اختلال اضطر اب اجتماعى كسب كردند بهطور تصادفى به دو

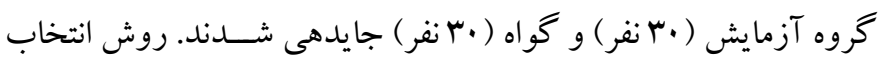

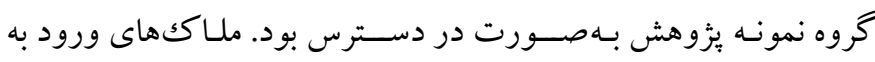
يزٔوهش شـامل: جنسيت دختر، تحصيل در يايه دهم دوره دوم متوسطه،

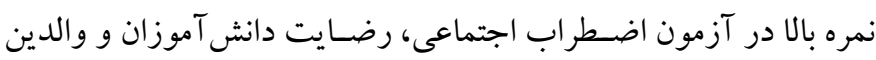

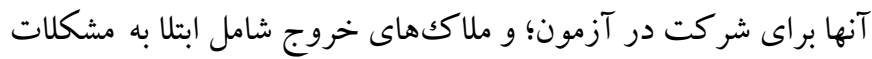

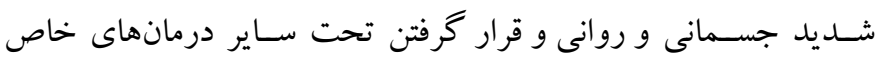

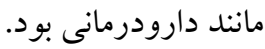

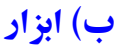
() برسـشنامه اضطراب اجتماعى كانور ': اين مقياس نخستين بار توسط

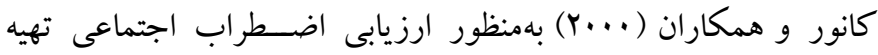

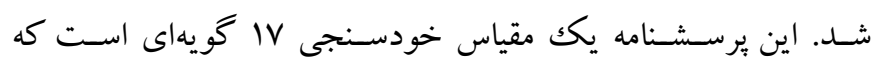

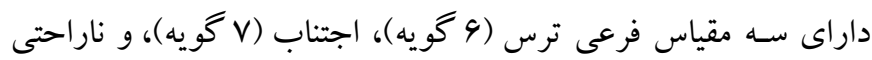

1. Conver Social Anxiety 
افر اد r ا ســال بـه بـالـا (هم افراد بهنجـار و هم جمعيتهاى بالينى) قابل

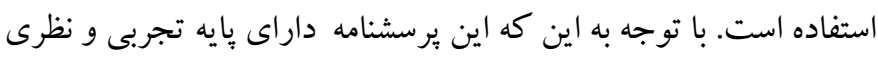

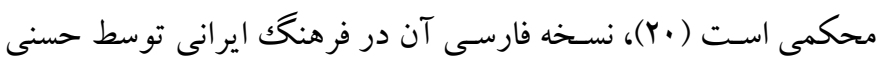

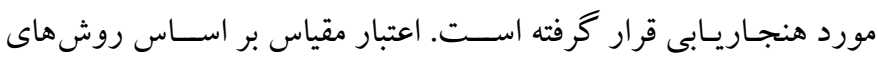

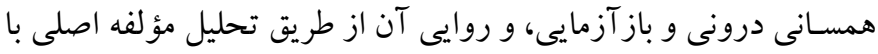

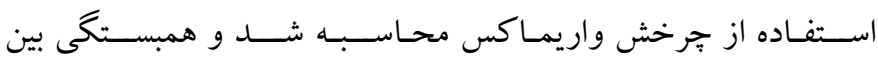

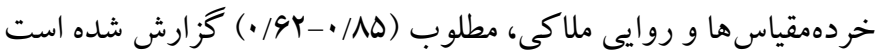

ج) برنامه مداخلهاى: شــيوه درمانى مورد اســفاده در بزّوهش، درمان مبتنى بر بذيرش و تعهد بود. در اين شيوه درمانى، تلاش مــى شـــود تـــا

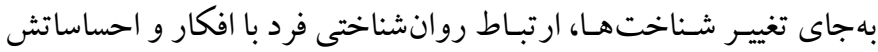

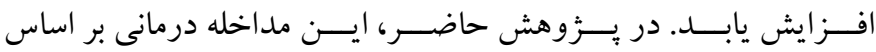

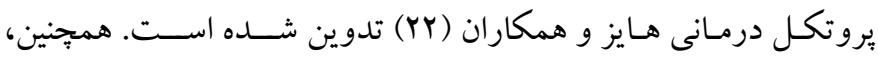

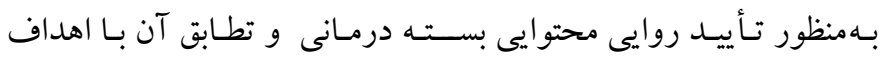
يُزوهش، با توجه به اين كه اين بسته درمانى استاندارد بود و در مجامع و

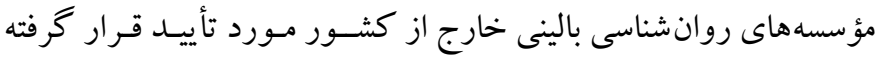

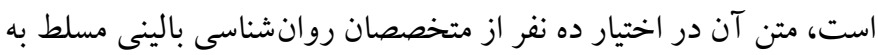

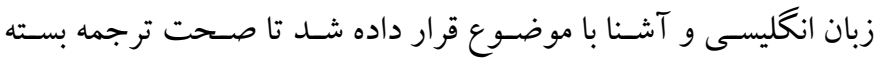

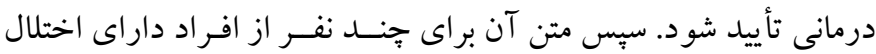

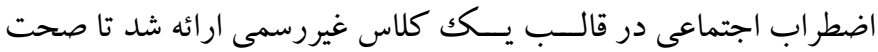

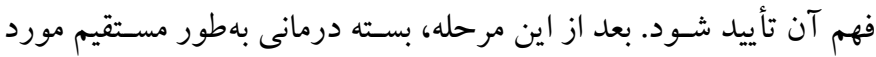

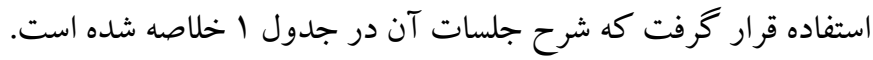

"r) مقياس شفقت به خود ': اين برسشـنامه توسط نف در سال ب...r ساخته

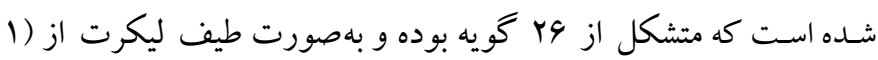

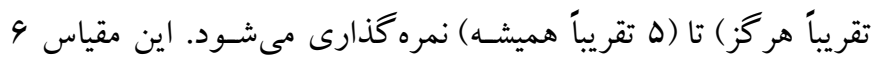

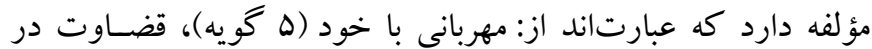

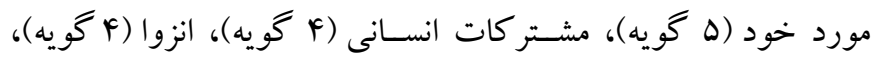

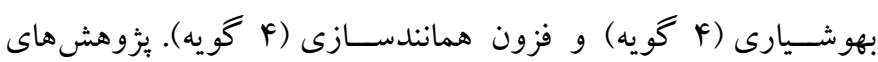

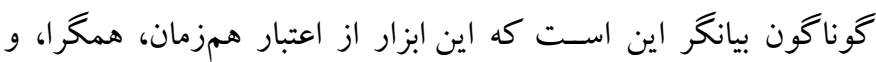

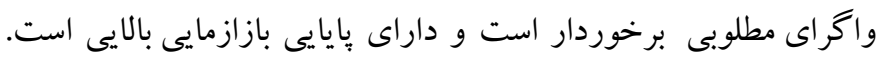

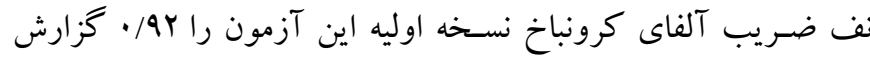

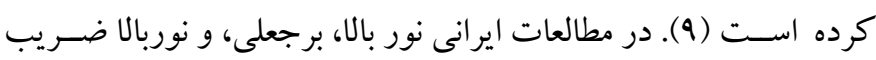

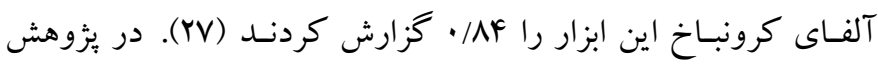

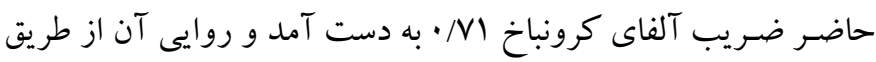
تحليل مؤلفه اصلى تأييد شده است.

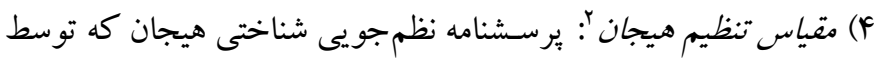

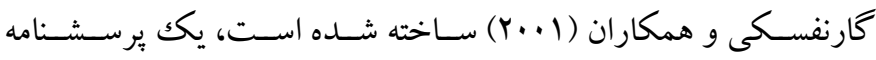
جندبعدى اسـت كه جهت شـناسـايى راهبردهاى مقابلهاى شــاختى افراد يس از تجربـه كردن وقـايع يـا موقعيـتهـاى منفى مورد اســفــاده قرار

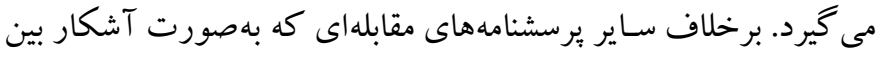
افكار فرد و اعمال واقعى وى تمايز قائل نمى شـوند، اين يرسـشنامه افكار

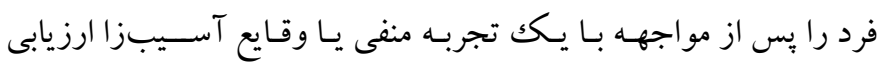

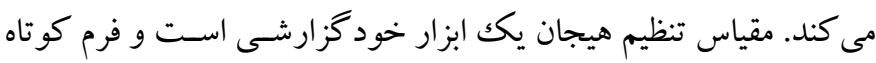

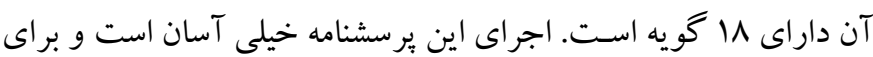

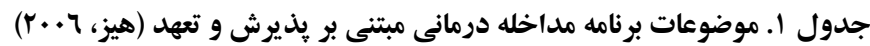

\begin{tabular}{|c|c|c|}
\hline تكليف ارائه شده & هدف & 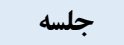 \\
\hline ثبت تجربههاى روزانه & برقرارى رابطه درمانى، بستن قرارداد درمانى، آموزش روانى & جلسه اول \\
\hline يادداشت روزانه و تمرين اوليه رفتارى & بحث در مورد تجربيات و ارزيابى آنها، كار آمدى بهعنوان معيار سنجش، ايجاد نااميدى خلاقانه & 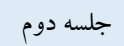 \\
\hline نار احتى پِاك در مقابل نار احتى نإياكك & بيان كنترل به بنوان مشكل، معرفى تمايل بهعنوان باسخى ديخر، در گير شدن با اعمال هدفمند & 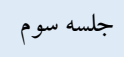 \\
\hline تمرين ذهن Tكاهى، بر گه راهنماى ذهن آكاهى جيست، & كاربرد فن هاى گسلش شناختى، مداخله در عملكرد زنجيرههاى مشكل ساز زبان، تضعيف ائتلاف خود با افكار و & جلسه جهارم \\
\hline استدلال به اعنوان علتها، ادامه تمرين ذهن آكاهى، تمرين & مشاهده خود به عنوان زمينه، تضعيف خود مفهومى و بيان خود بهعنوان مشاهده گر، نشان دادن جدايى بين خود، & جلسه بنجم \\
\hline 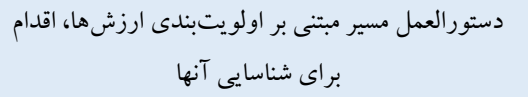 & كاربرد فن هاى ذهنى، الكوسازى خروج از ذهن، آموزش ديدن تجربيات درونى بهعنوان يكك فرايند & جلسه ششم \\
\hline
\end{tabular}


فعال سازى رفتارى (تعهد دستيابى به اهداف كوجك تر

تعيين شده مانند سازش يافتخى).

معرفى ارزش، نشان دادن خطرات تمركز بر نتايج، كشف ارزشهاى عملى زندگى

جلسه هفتم

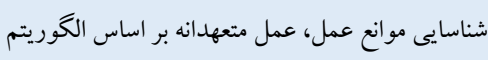

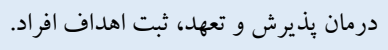

در كك ماهيت تمايل و تعهد، تعيين الكوهاى عمل متناسب با ارزشها

جلسه هشتم

والـدين دانش آموزان در تمـامى مراحل ئزوهش در جريان فرايند مطالعه

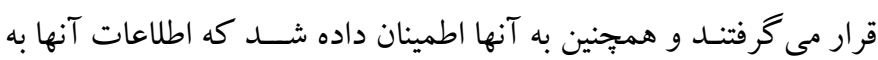

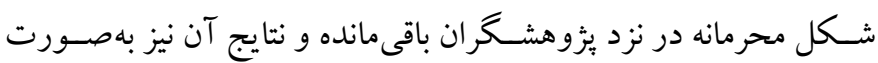

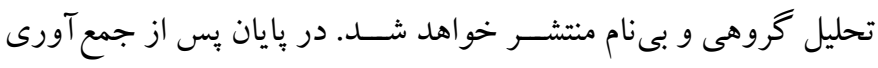
دادهها، تجزيه و تحليل با كمكك آزمون كوواريانس انجام شد.

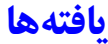

شاخص هاى آمار توصيفى نظير ميانگين و انحر اف معيار و همجنين نتايج

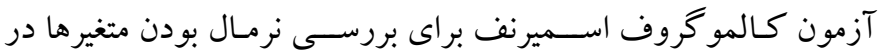

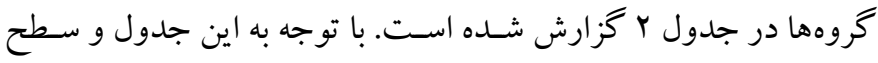
معنادارى آماره Z مى توان نتيجه كرفت توزيع متغير ها نرمال هستند.
د) روش اجرا: بس از همـاهنكى و اخــ مجوز از كـارگروه اخلـاقى

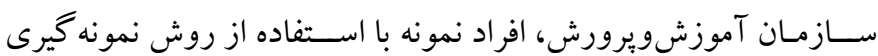
تصادفى از بين مر اجعين به مركز مشـاوره منطقه م تهران، انتخاب شدند.

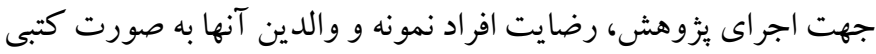

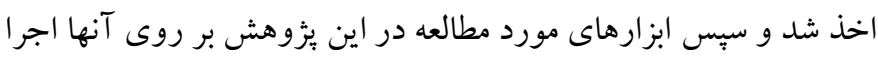

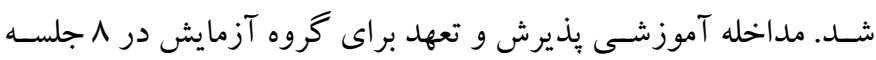
• r ا دقيقه با فاصله هل روز بين جلسـات ارائه شد. هدف از اين برنامه اين اســت كه نوجوان با دركك ماهيت واقعى عوامل تشــــيد كننده روانى و

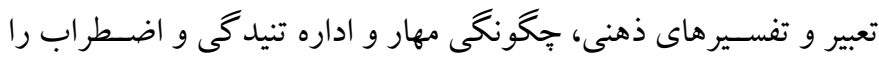

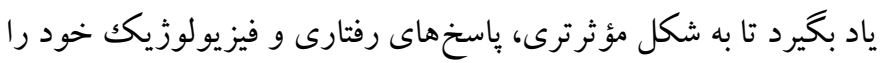

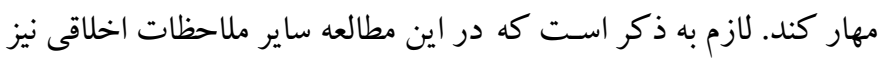

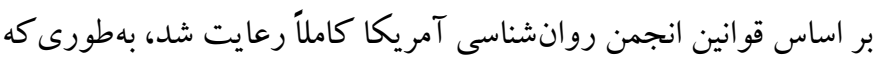

جدول r: شاخصهاى مر كزى و يراكندكى دو كروه در متغيرهاى بزوهش

\begin{tabular}{|c|c|c|c|c|c|c|c|}
\hline \multicolumn{2}{|c|}{ كالمو كروف اسميرنوف } & \multicolumn{2}{|c|}{ هـ آزمون } & \multicolumn{2}{|c|}{ بيش آزمون } & \multirow{2}{*}{ كروه } & \multirow{2}{*}{ متغير } \\
\hline $\mathbf{P}$ & K-S Z & SD & $\mathbf{M}$ & SD & $\mathbf{M}$ & & \\
\hline$\cdot / V^{F}$ &.$/ 91 \mu$ & $9 / \pi 1$ & $r q / \mu v$ & $F / \Delta V$ & $91 / 9$. & آزمايش & \multirow[b]{2}{*}{ اضطراب اجتماعى } \\
\hline - $/ V \Delta Q$ & $.19 \mathrm{VI}$ & $F / F D$ & $\Delta Q / 1$. & $r / 99$ & 9.19. & كواه & \\
\hline$\cdot / 4 \wedge \Delta$ & ./ArV & $9 / 91$ & $9 Y / 9 V$ & $F / A r$ & $99 / 1 \mathrm{~V}$ & آزمايش & \multirow{2}{*}{ شفقت به خود } \\
\hline$\cdot / \Delta \Delta 1$ & •/V৭4 & $\Delta / r$ & $99 / 4$ & $\Delta / \mu q$ & GN/VV & كواه & \\
\hline$\cdot / F Y$ & $\cdot / M \Lambda$. & $r / v q$ & $19 / \pi r$ & $r / r$ & $1 . / 9 V$ & آزمايش & \multirow{2}{*}{ مهربانى با خود } \\
\hline$\cdot / 4 q$ & . /ATF & $r / 99$ & $\mid r / \cdot V$ & $r / 9 q$ & $I T / Y$ & كواه & \\
\hline -/VDG &.$/ 9 \mathrm{VI}$ & $1 / 91$ & 1./rr & $r / V r$ & $\mid f / A$ & آزمايش & \multirow[b]{2}{*}{ قضاوت در مورد خود } \\
\hline . & $\cdot / \mathrm{V} \Delta \Lambda$ & $1 / \Delta 9$ & $1 \cdot 19$ & $1 / M$ & $1.19 \mathrm{~V}$ & كواه & \\
\hline$\cdot / \Delta \mathrm{VA}$ & $\cdot /$ V 9 & $1 / \wedge \Delta$ & IV/9T & $r / Y I$ & $11 / 94$ & آزمايش & \multirow{2}{*}{ مشتر كات انسانى } \\
\hline$\cdot / T V A$ &.$/ 91$. & T/YQ & $11 / \pi V$ & $r / T^{4}$ & $11 / F V$ & كواه & \\
\hline$\cdot / \mu \cdot 9$ & ./9Y9 & $1 / 11$ & $\Lambda / 9$ & l/Vr & $I \pi / V$ & آزمايش & \multirow{2}{*}{ انزوا } \\
\hline$\cdot / \Delta 99$ & $\cdot / V 9 V$ & $1 / 9 \mathrm{~V}$ & $1 r / 4$ & $1 / 9$ & $|r /|$ & كواه & \\
\hline $.19 \mathrm{VV}$ & $\cdot / V Y$. & $r / \cdot 1$ & IF/T & $r / r V$ & $9 / r$ & آزمايش & \multirow{2}{*}{ هوشيارى } \\
\hline$\cdot / V 90$ & $.199 \mathrm{~V}$ & $1 / \mathrm{VA}$ & Q/AV & l/AF & $9 / V^{r}$ & كواه & \\
\hline$\cdot /$ rAV & $\cdot / 9 \cdot 4$ & $1 / 11$ & $\Lambda / r V$ & $r / 9 V$ & $11 / T V$ & آزمايش & \multirow{2}{*}{ فزون همانندسازى } \\
\hline •/VAV & $.190 r$ & $r / I r$ & 1. & $r / r)$ & $1 . / 14$ & كواه & \\
\hline.$|94|$ & - /VDF & $F / \Delta \Delta$ & $\Delta r / 9$ & $r / 11$ & rN/qV & آزمايش & \multirow{2}{*}{ تحمل يريشانى } \\
\hline . /QFY & . /Drq & $r / 41$ & $F \cdot / A V$ & $\mathrm{r} / \mathrm{M}$ & rq/qV & كواه & \\
\hline
\end{tabular}




\begin{tabular}{|c|c|c|c|c|c|c|c|}
\hline$\cdot / \mathrm{V} \Lambda$ & $1 / r V r$ & $1 / \Delta 9$ & $\| / F V$ & $1 / r$ & $\mathrm{~V} / A \mathrm{~V}$ & آزمايش & \multirow{2}{*}{ تحمل } \\
\hline . /YFV & $1 / \cdot Y r$ & $1 / \wedge 1$ & $\Lambda / F V$ & $1 / 94$ & N/I & كواه & \\
\hline - KFV & - /AVG & $1 / 09$ & $11 / 4$ & $1 / \Delta \Delta$ & N/r & آزمايش & \multirow{2}{*}{ جذب } \\
\hline •/YAV & ./QAF & $1 / F V$ & $N / 9 \pi$ & $1 / \Delta V$ & N/9 & كواه & \\
\hline$\cdot / \Delta I V$ & ·/AIV & Y/QV & IV/Ar & $r / \Delta r$ & $1 \pi / 9$ & آزمايش & \multirow{2}{*}{ ارزيابى } \\
\hline .1949 & $\cdot / V T V$ & $1 / 99$ & $1 F / 9$ & $r / M r$ & $\mid F / r$ & كواه & \\
\hline.$/ 199$ & $1 / 111$ & $1 / \Delta r$ & $\mid r / \cdot r$ & $1 / 4$ & N/qV & آزمايش & \multirow{2}{*}{ تنظيم } \\
\hline - /YYV & $1 / \cdot k r$ & $1 / \pi \Delta$ & $9 / 1$ & $1 / \% \Lambda$ & $9 / \cdot r$ & كواه & \\
\hline$\cdot / r \cdot q$ & $1 / .94$ & $\Delta / 1$. & & $r / q$ & $\mathrm{FV} / \mathrm{VV}$ & آزمايش & \multirow{2}{*}{ تنظيم هيجان } \\
\hline$\cdot / 0 \cdot 1$ & .1949 & $r / \Lambda \Lambda$ & $r q / r$. & $r / \cdot \Lambda$ & $\mathrm{Fq/FT}$ & گواه & \\
\hline
\end{tabular}

براى بررسـى تأثير آموزش درمان مبتنى بر يذيرش و تعهد بر كاهش اضــطراب اجتمـاعى در دانش آموزان از تحليل كوواريانس تككمتغيرى برى بركي اسـتفاده شــده اســت. در جدول ب نتايج تحليل كوواريانس تككمتغيرى براى بررسسى تفاوت گروه آزمايش و گو اه در يِيش آزمون با يس آزمون متغير هاى يزؤهش (اضـطراب اجتماعى، شفقت به خود، تحمل بريشانى، و تنظيم هيجان) گزارش شـده اسـت. نتايج آزمون همكونى شــبـهاى ركرسيون بيش آزمون و يس آزمون اضطراب اجتماعى در گروه آزمايش

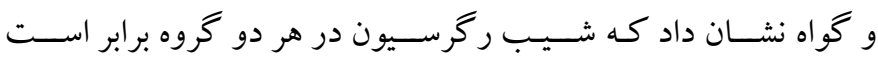

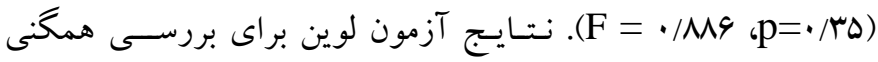

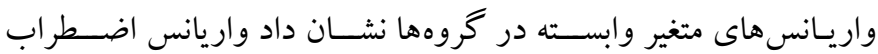

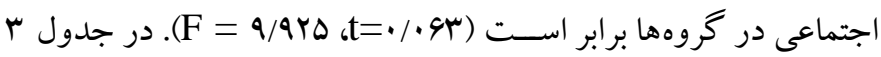
نتـايج تحليـل كوواريانس تككمتغيرى جهت بررسـى تفاوت گرووه آزمايش و كواه در متغيرهاى بزَوهش گززارش شده است.
بر اســاس اطلـاعـات ارائـه شـــده در جدول Y، در متغير اضـــراب اجتماعى، بررسـى ميانگين دو گروه در مرحله يِيش آزمون و بس آزمون مؤيد آن است كه نمرات يس آزمون (T/RV) شر كت كنند كان در كروه آزمايش، نسبت به نمره بيش آزمون ( •91/9) كاهش داشته است. لازم به ذكر اسـت در اين آزمون كسـبـ نمره يايينتر، نشــاندهنده اضـطر اب اجتماعى كمتر بعد از دوره درمان است. بررسى ميانگينهاى دو گروه در متغير شـفقت به خود نشــان مىدهد در مرحله بس آزمون ميانكين گروه آزمـايش (9Y/GV) افزايش داشــته اســت كه اين ميانكين، نشـــاندهنده افزايش شـفقت به خود بعد از دوره درمان اسـت. همجيخنين در متغيرهاى تحمـل بريشــانى و تنظيم هيجـان در مرحلـه بِ آزمون، ميـانكين كروه آزمايش افزايش داشته است كه نشان از تأثير دوره درمان بر دانش آموزان

جدول بّ: نتايج تحليل كوواريانس تككمتغيرى جهت بررسى تفاوت كروه آزمايش و كواه در متغيرهاى بزوهش

\begin{tabular}{|c|c|c|c|c|c|c|c|}
\hline ميزان تأثير & سطح معنادارى (P) & T Tlo & ميانكين مربعات & درجه آزادى & مجموع مربعات & منبع & متغير \\
\hline$\cdot / Y 9 V$ & $\cdot / \cdots 1$ & YF/IYA & $\Delta r Y / \Delta \Delta$ & 1 & $\Delta r I / \Delta \Delta$ & ي بيش آزمون & \\
\hline \multirow[t]{2}{*}{. $/ \Delta$ H } & $\cdot / \cdots 1$ & TMN/AIV & GTFY/.Ar & 1 & GTFT/.Ar & كروه & \\
\hline & & & $r 1 / 919$ & $\Delta V$ & $\mid Y M r / 119$ & خطا & \\
\hline.$/ 111$ & $\cdot \cdots \cdot 1$ & V/GFF & FrN/Y.Y & 1 & FrN/Y.r & بيش آزمون & \\
\hline \multirow[t]{2}{*}{.$/ 9 K F$} & $\cdot / \cdots 1$ & $199 / 199$ & $\Lambda \Delta \Delta r / \cdot F \Lambda$ & 1 & $\Lambda \Delta \Delta r / \cdot F \Lambda$ & كروه & is 1 \\
\hline & & & $\Delta \mathrm{V} / \mathrm{TTV}$ & $\Delta V$ & rYGV/990 & خطا & \\
\hline$\cdot / \Delta 9 \mathrm{~V}$ & $\cdot / \cdots 1$ & $\Lambda F / M F \Delta$ & $\Delta \Delta N / q \Gamma \Lambda$ & 1 & $\Delta \Delta \Lambda, Q \top \Lambda$ & ييش آزمون & \\
\hline \multirow[t]{2}{*}{$\cdot 1091$} & $\cdot / \cdots 1$ & $\mathrm{r} \Delta \mathrm{Y} / \mathrm{MA}$ & YMTN/FVT & 1 & rmTN/FVT & گروه & $3 \frac{3}{3}$ \\
\hline & & & 9/9TV & $\Delta V$ & rWV/vrq & خطا & \\
\hline.$/ 09$ &.$/ \cdot 1$ & $\Lambda Y / . q r$ & $V I \cdot / N \mid r$ & 1 & $V I \cdot / A I r$ & ييش آزمون & 政. \\
\hline \multirow[t]{2}{*}{.1090} & $\cdot / \cdot \cdot 1$ & IND/AFY & $19 \cdot 9 / V Y$ & 1 & $19 \cdot 9 / V Y$ & گروه & $\xi$ \\
\hline & & & N/99Y & $\Delta V$ & FqY/VYI & خطا & 5 \\
\hline
\end{tabular}




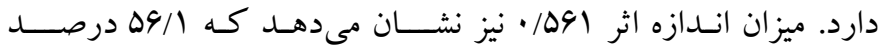

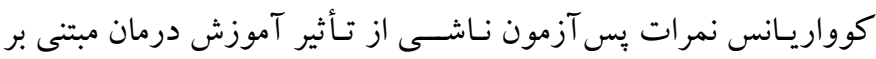
يذيرش و تعهد بر افزايش تحمل بريشانى در دانش آموزان است.

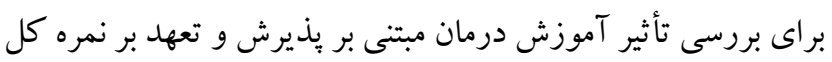

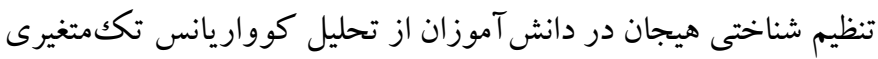

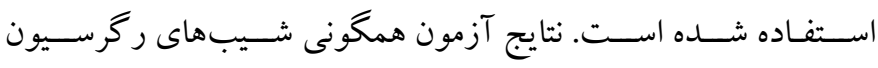

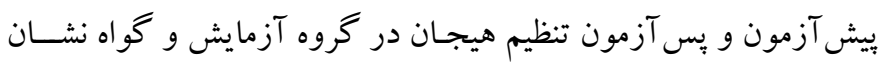

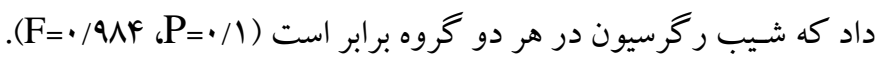

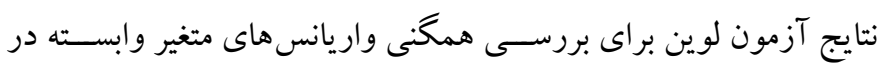

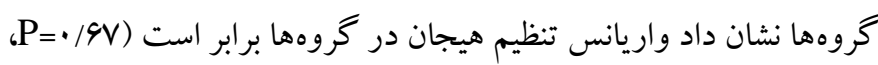

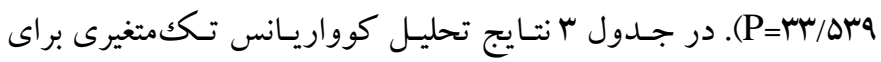

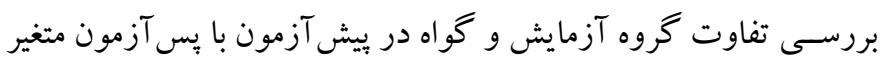

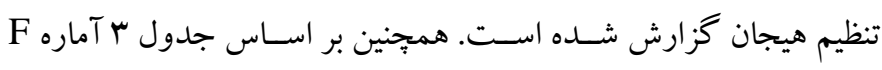

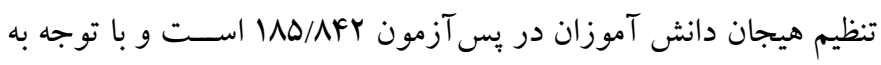

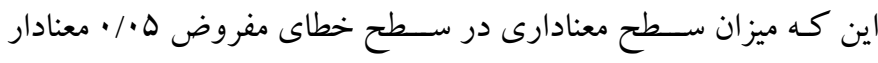

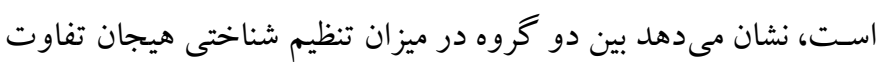

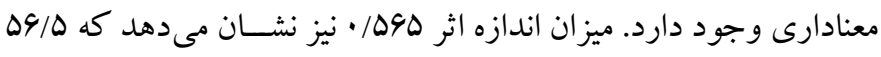

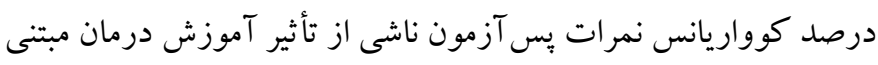
بر بذيرش و تعهد بر تنظيم هيجان در دانش آموزان است.

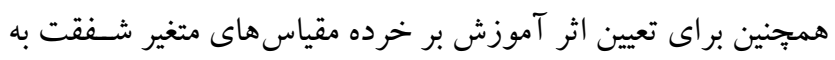

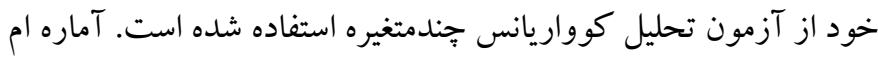

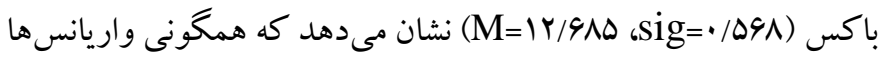

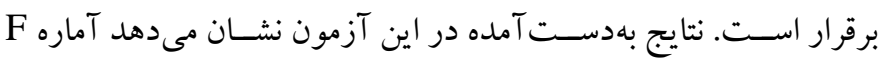

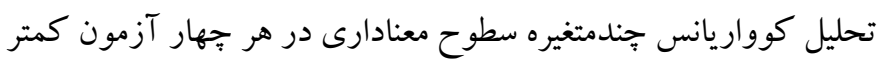

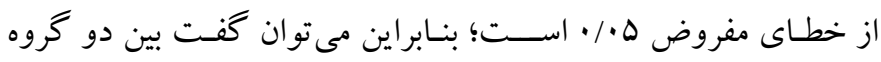

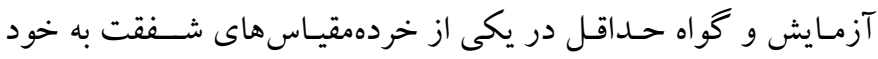

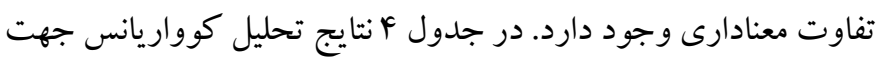

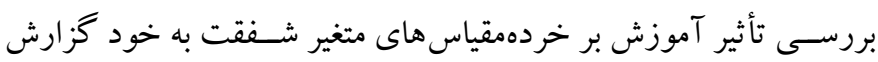

بـا توجـه بـه جدول ץ آماره F اضـطر اب اجتماعى دانش آموزان در

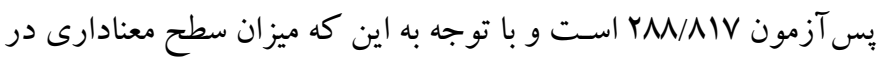

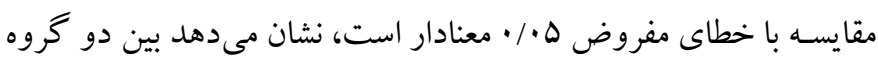

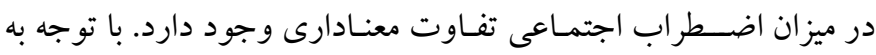

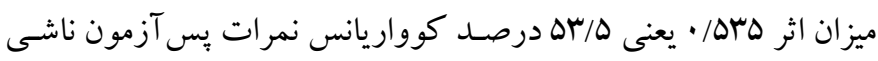

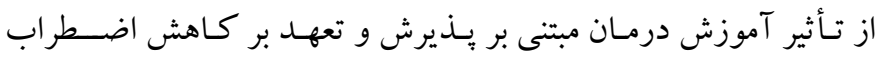
اجتماعى در دانش آموزان است. براى بررسـى تأثير آموزش درمان مبتنى بر يذيرش و تعهد بر بر نمره

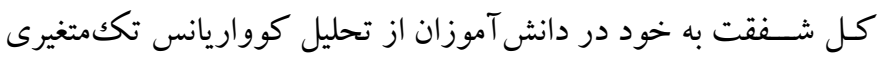

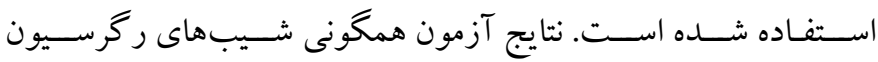

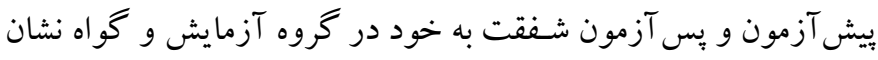

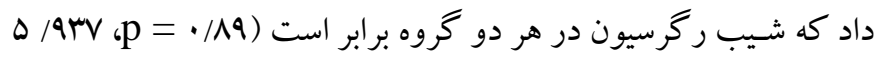

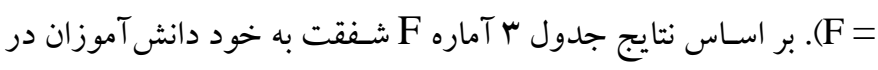

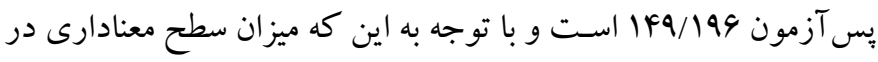

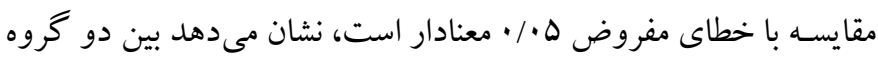

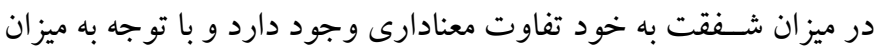

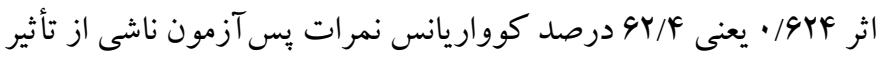

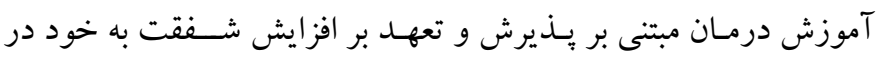
دانش آموزان است. براى بررسى تأثير آموزش درمان مبتنى بر يذيرش و تعهد بر نمره كل

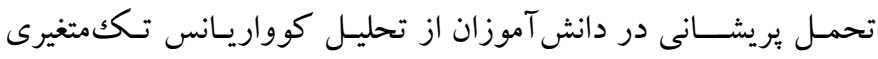

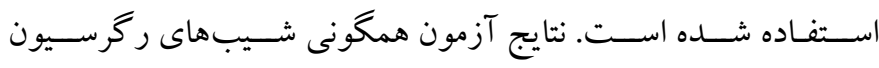

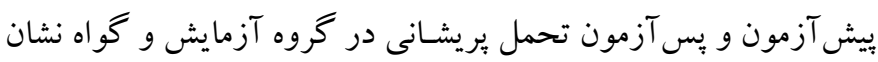

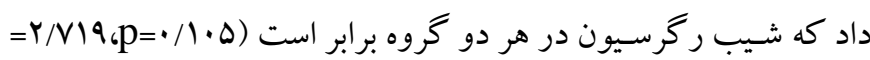
F

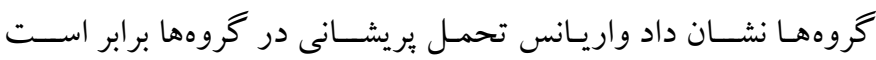

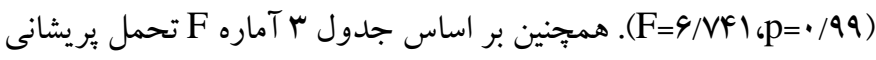

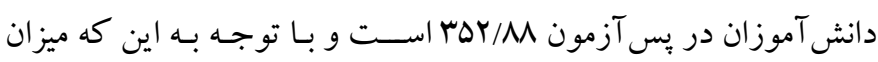
سطح معنادارى در مقايسـه با خطاى مفروض هـ هـ ـ • معنادار اسـت، نشـان

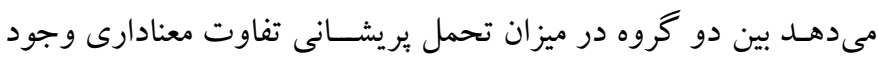


جدول ع: نتايج تحليل كوواريانس جهت بررسى تأثير آموزش بر خردهمقياسهاى متغير شفقت به خود

\begin{tabular}{|c|c|c|c|c|c|c|}
\hline ميزان تأثير & سطح معنادارى & Tاره F F & ميانغين مربعات تروه & درجه آزادى كروه & مجموع مربعات كروه & متغير \\
\hline$\cdot / 099$ & $\cdot / \cdots \cdot 1$ & $1 \wedge 9 / 9 \wedge \Delta$ & f../991 & 1 & F../991 & مهربانى با خود \\
\hline ( & $\cdot / \cdots+1$ & YN/HYQ & $\Delta I / Y Y F$ & 1 & $\Delta I / Y Y F$ & قضاوت در مورد خود \\
\hline$\Delta F q$ & $\cdot / \cdots 1$ & $\mid V \cdot / 1 \Delta \Lambda$ & $\Delta F T / 9 \Delta \Lambda$ & 1 & $\Delta F T / 9 \Delta \Lambda$ & مشتر كات انسانى \\
\hline .191. & $\cdot / \cdots 1$ & TFY/ATA & ५৭८/V৭৭ & 1 & Ү৭1/V৭৭ & انزوا \\
\hline ./FVG &.$/ \cdots 1$ & $199 / 90 \mathrm{~V}$ & TFY/VIQ & 1 & TKY/VIQ & هوشيارى \\
\hline . /Drq & $\cdot / \cdots+1$ & $99 / \vee 19$ & Al/AVr & 1 & Al/AVr & فزون همانندسازى \\
\hline
\end{tabular}

واريانس ها برقرار اسـت. نتايج بهدسـت آمده در اين آزمون نشان مىدهد آمـاره F تحليـل كوواريـانس جندمتغيره ســوح معنادارى در هر جهار آزمون كمتر از خطاى مفروض ه • • • اســت، بنابراين مى توان كفت بين دو گروه آزمـايش و كو اه حسداقـل در يكى از خردهمقيـاسهـاى تحمـل بريشــانى تفـاوت معنـادارى وجود دارد. در جــدول ه نتـايج تحليـل كوواريانس جهت بررسـى تأثير آموزش بر خردهمقياسهاى متغير تحمل

$$
\text { يريشانى كزارش شده است. }
$$

بـا توجسه بـه جـدول F آموزش درمـان مبتنى بر يـذيرش و تعهــ بر خردهمقياس هاى شفقت به خود در دانش آموزان تأثير معنادارى دارد و با توجـه بـه ميانكين ها، باعث افزايش و بهبود مهربانى به خود، مشــتر كات انسانى و هوشيارى، و كاهش مقياس هاى قضاوت در مورد خود، انزوا، و فزون همانندسازى مىشود. همجينين براى تعيين اثر آموزش بر خردهمقيـاسهـاى متغير تحمـل يريشـانى از آزمون تحليل كوواريانس جندمتغيره اسـتفاده شــده اسـت. آماره ام باكس (M=10/919، sig=•/101) نشــان مىدهد كه همكونى

جدول 0: نتايج تحليل كوواريانس جهت بررسى تأثير آموزش بر خردهمقياسهاى متغير تحمل بريشانى

\begin{tabular}{|c|c|c|c|c|c|c|}
\hline ميزان تأثير & سطح معنادارى (P) & Tاره F T & ميانكين مربعات كروه & درجه آزادى كروه & مجموع مربعات كروه & متغير \\
\hline$\cdot / \& V V$ & $\cdot / \cdots \cdot 1$ & $119 / 0.4$ & $10 \Delta / 99 V$ & 1 & $10 \Delta / 99 \mathrm{~V}$ & تحمل \\
\hline . /DrY & $\cdot / \cdots 1$ & $10 \Delta / \wedge 9 \Delta$ & ITVIAFY & 1 & ITVIAFY & جذب \\
\hline - /DFY & $\cdot / \cdots 1$ & $q V / F V I$ & $10 . / 110$ & 1 & $10 . / 110$ & ارزيابى \\
\hline.$/ 491$ & $\cdot / \cdots 1$ & $r Y \Delta / \cdot \Delta$ & $|r F /| V \mid$ & 1 & $|\mu q /| V \mid$ & تنظيم \\
\hline
\end{tabular}

\section{بحث و نتيجه تيرى}

يثزوهش حاضسر با هدف بررسى اثربخشى درمان مبتنى بر يذيرش و تعهد برافزايش شفقت به خود، تحمل بريشانى و تنظيم هيجان در دانش آموزان با اختلال اضــطراب اجتماعى در دوره متوســطه انجام شــــ. نتايج تحليل كوواريانس تكك متغيرى نشــان داد كه درمان مبتنى بر يذيرش و تعهد در مرحلـه يس آزمون منجر بـه كـاهش اضــطراب در دانش آموزان داراى اضـطراب اجتماعى فراكير نسـبت به گروه گو اه شــده اسـت. اين يافته بهوطور ضمنى با ئزوهش هافمن و همكاران (Y9) همسو و همخوان است.
بـا توجسه بـه جـــول ه آموزش درمـان مبتنى بر يـذيرش و تعهــ بر خردممقياس هاى تحمل ير يشانى در دانش آموزان تأثير معنادارى دارد و با توجه به ميانگين ها باعث افزايش و بهبود تحمل يريشـانى هيجانى، جذب هيجانات، ارزيابى ذهنى يريشـانى، و تنظيم تلاشها براى تسكين بريشانى شده است. 
هوشسيارانه از آنجه در ذهن مى گذرد و ديد گاه فارغ از قضساوت همراه با فيا

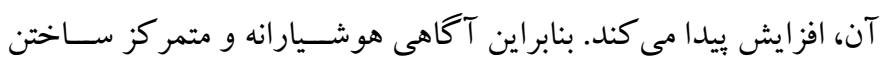

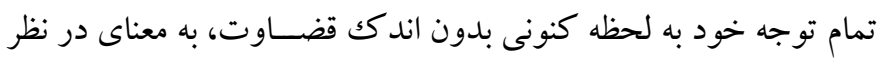

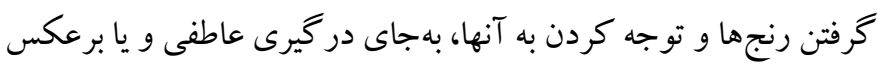

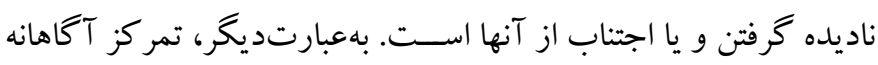
شامل وارد شدن به احساسات دردناكك در مقابل غرق شدن در آنها است.

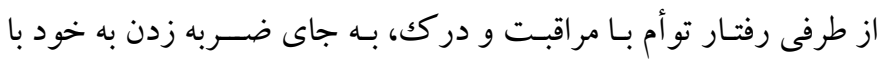
انتقادهاى سـخت و شـديد مى تواند در تحمل رنج هاى ذهنى هيجانى كه ونه بخشى از تجربه انسـانى است كمك كند. همجنين باعث مى شود مر اجع

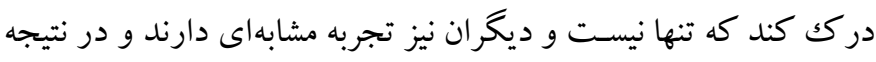
اين شيوه به مدد اصل اشتراكات انسانى، مى تواند اثربخش باشد. همجنين

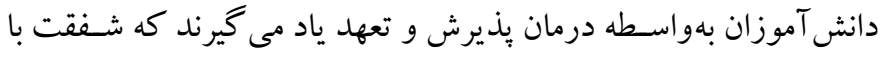

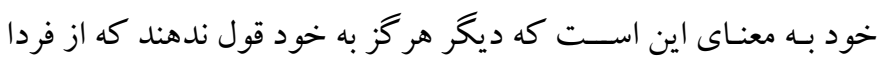

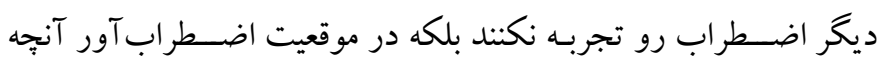

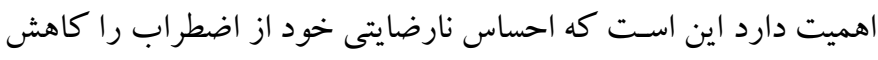
دهند، با ناراحتى جســمانى و عاطفى خود دوســت شــوند، و مانند يكك

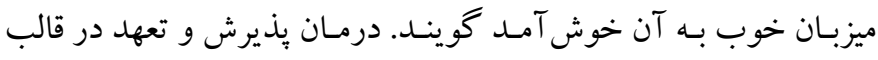

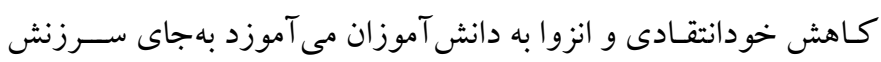
خود، بهتر اسـت از زيادهروى هاى خود در اضـطر اب جلو خيرى كنند.

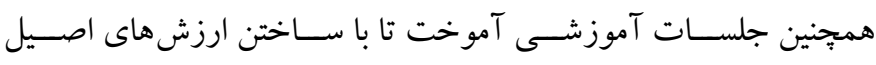

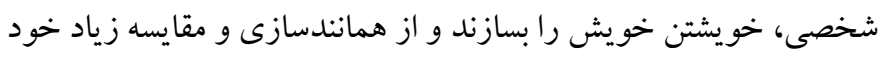

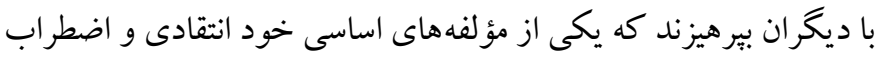

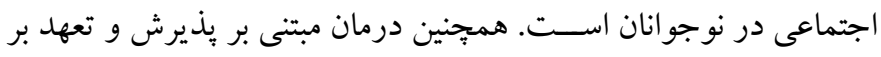

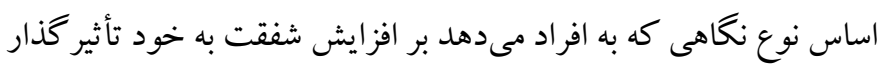

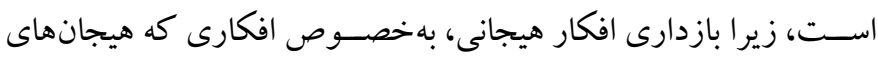

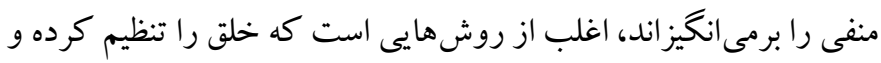

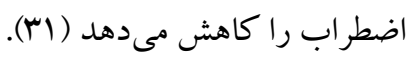

ديخر يافته اين بثزوهش نشــان داد كه اختلاف معنادارى بين ميانگين

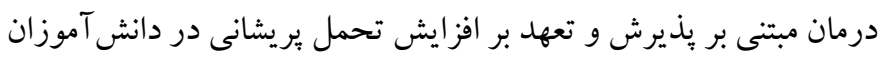

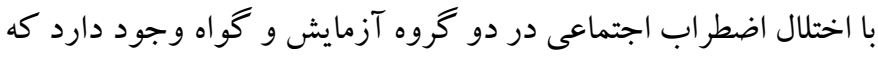
اين يافته در راستاى يزوهش شيدايى اقدم و همكاران (19) است كه نشان

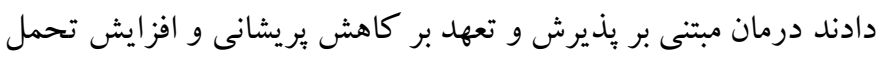

يافتهاى اين يُزوهش مؤيد آن اسـت كه در درمان مبتى بر بذيرش و تعهد به دانش آموزان آموخته مىشــود كه بهجاى اجتناب فكرى و و

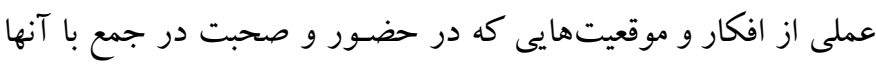
روبرو مىشـوند با افزايش بذيرش روانى و ذهنى نسـبت به تجارب

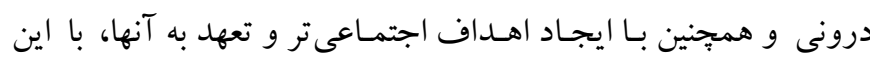

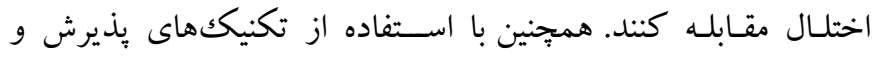
كسلش كه شامل استعاره به آنها و تمرينها بود، دانش آموزان با افكار

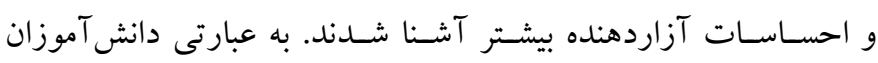

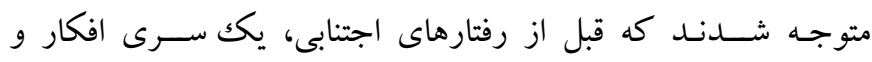

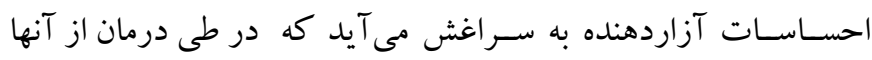

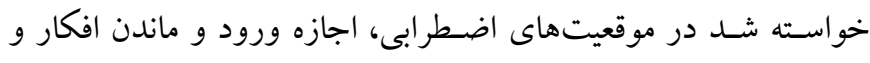

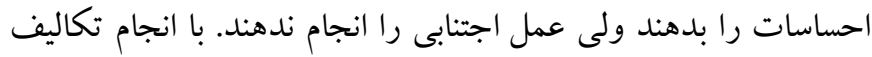

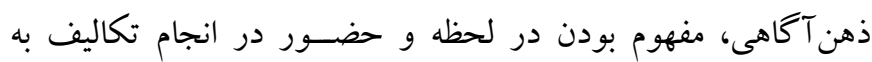

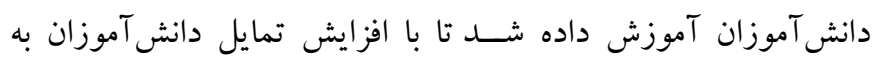
تجربـه رويدادهاى درونى همانطور كه هســت، از انجام رفتارهاى

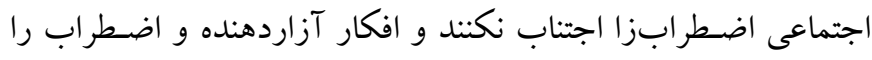
فقط بهعنوان فكر و احسـاس تجربه كنند. درواقع رويارويى فعال و مؤثر

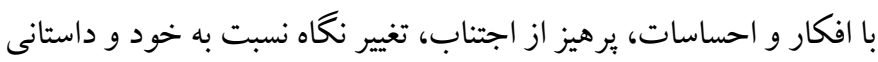

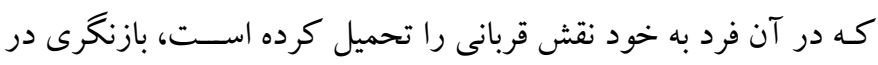

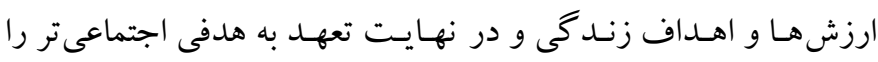
مى توان جزء عوامل اصلى مؤثر در اين روش درمانى دانست (Yr).

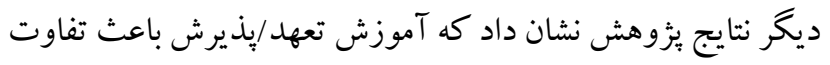

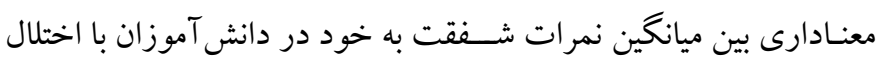

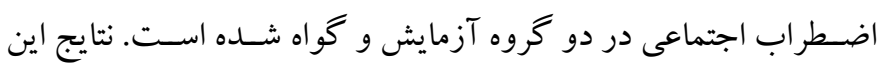

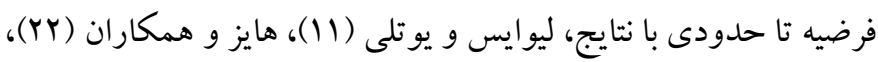

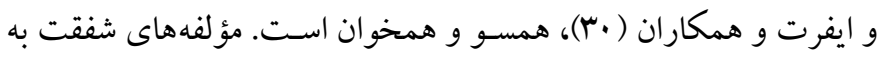
خود از جمله مهربانى با خود، مشتركات انسانى، و هوشيارى، تحت تأثير هوران

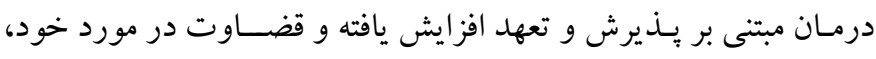
انزوا، و فزون همانندسازى كاهش يافته است. شفقت به خود با حساسيت به رنج خود و ديكران آغاز شده و با گسترش همدلى با اين رنج و و ايجاد

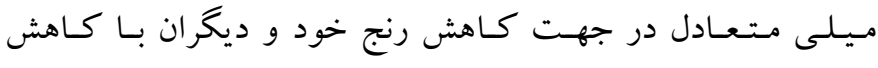

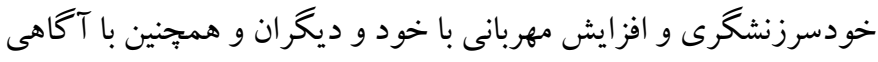


بهطورى كه ناتوانى در مهار هيجان منفى، ناشى از وجود افكار و باورهاى

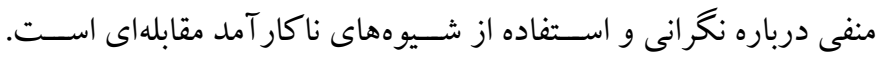

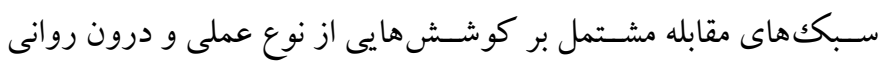

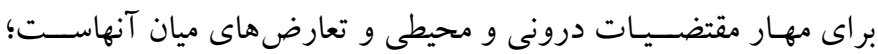
بنابر اين مفهوم تنظيم هيجان بهدقت مرتبط با مفهوم مقابله است. فريس و

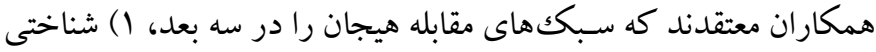

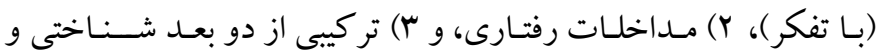

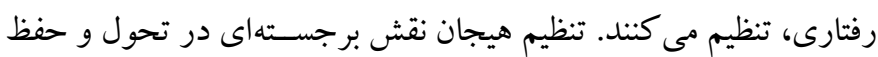

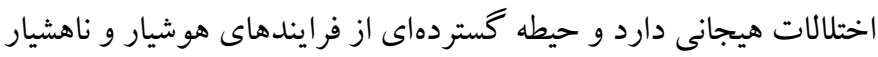

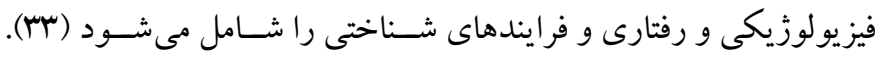
مى توان كفت دانش آموزانى كه راهبردهاى منفى تنظيم هيجان دارند در

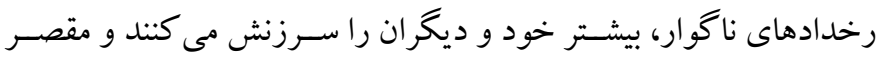

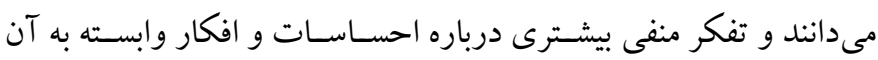
رخــاد منفى دارنـــ. در مقـابل افراد داراى راهبرهاى مثبت تنظيم هيجان

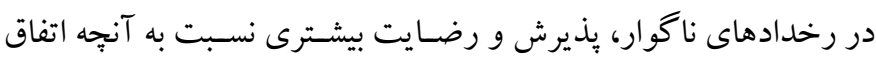

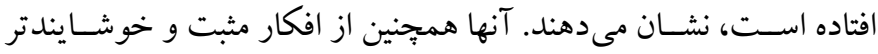
بيشـترى دربـاره نحوه رويسارويى بـا حادثهاى تلخ و كامهاى مورد نياز

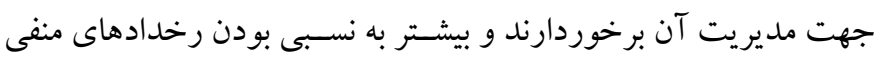

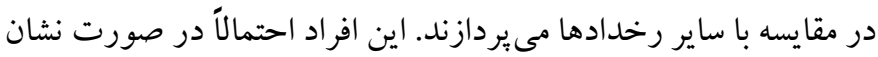
دادن عملكرد ضـعيف در روابط بينفردى و يـا در موقعيـت تنش آور

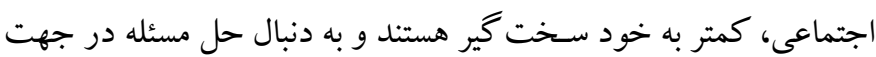
بهبود عملكرد اجتماعى و نگًاه مثبت به آن هستند ( ·. (Y). از محدوديتهاى يزٔوهش حاضـر، فراهم نشــدن شـرايط انتخاب و

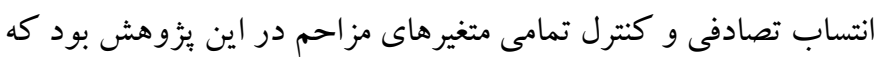

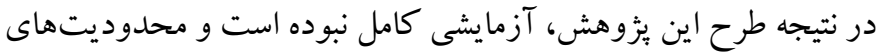

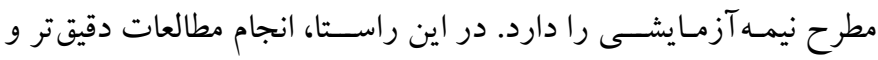

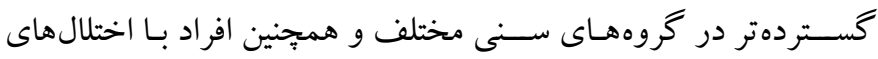

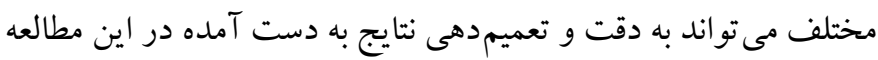
بيفز ايد. همجنين بيشـنهاد مى شـود با توجه به نقش خودشـفقتى و تنظيم

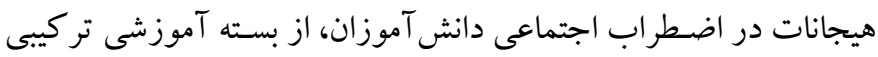

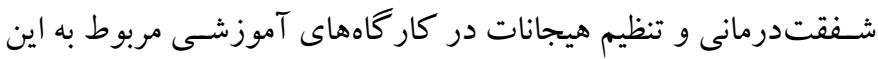

يريشــانى، مؤثر اسـتـ. ثئوهش ديخرى كه دقيقاً تأثير درمان بذيرش و تعهد بر تحمل بريشـانى را بررسـى كرده باشــد، يافت نشـــ. طبق نظريه

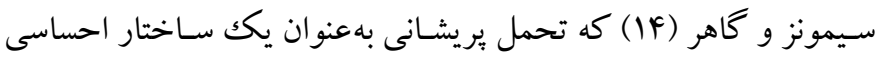

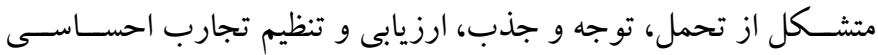

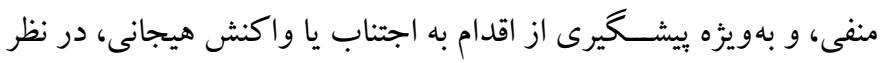

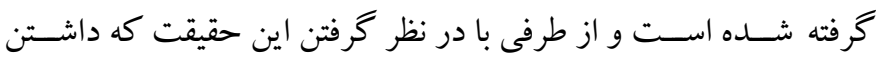

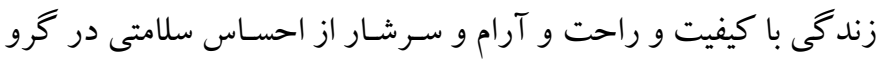
يذيرش احساسات منفى و مثبت در قدم اول، و تعهل به كاهش احساسات

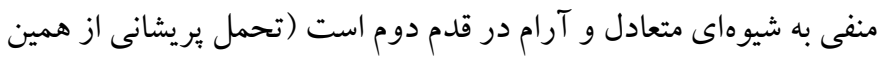

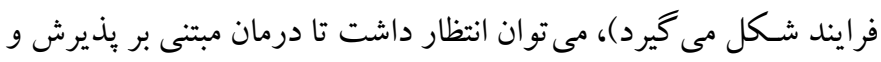

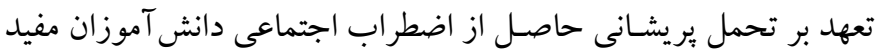

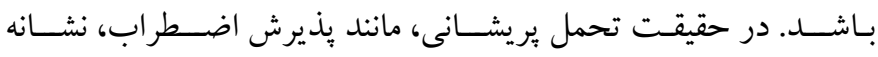

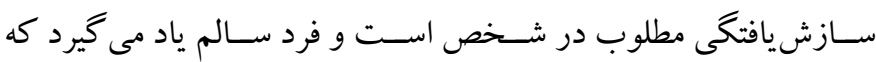

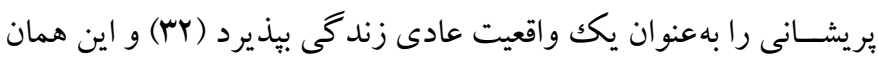

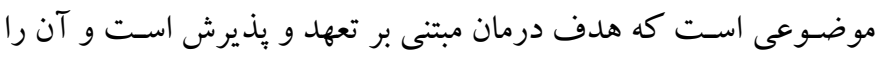

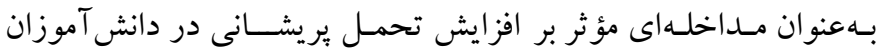

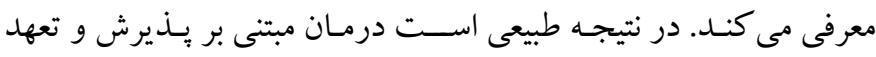

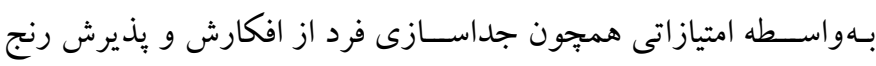

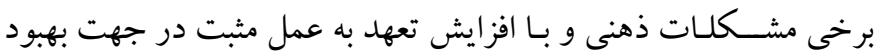
خود بر تحمل بريشانى دانش آموزان مؤثر باشد.

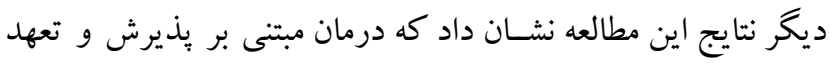

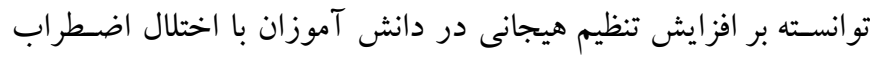

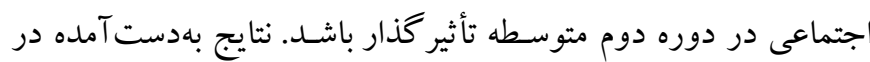

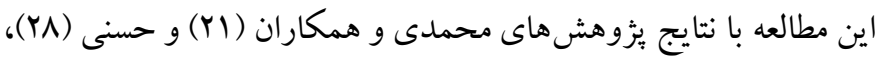

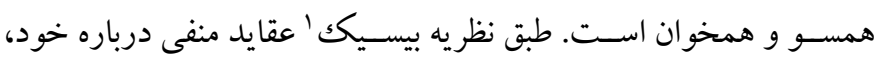

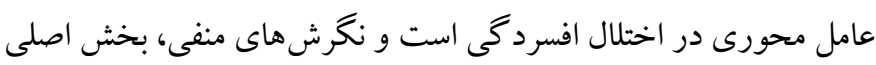

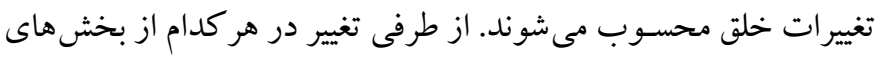

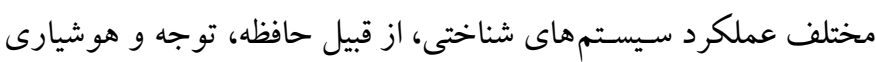
موجـب تغيير خلق مىشـــــ؛ بنـابر اين نمى توان نقش تنظيم هيجان را در

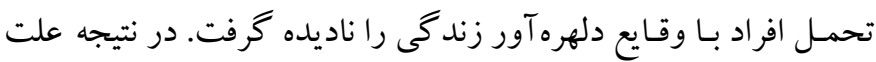
اختلالات هيجانى به نارسايى در كنترلهاى شناختى نسبت داده مى شوده،

1. Basics 


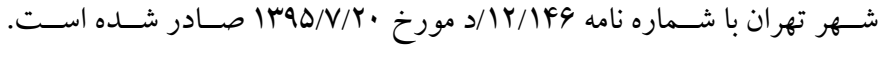

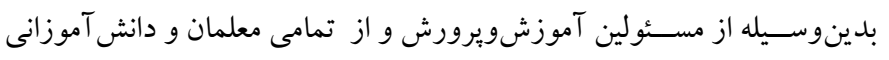

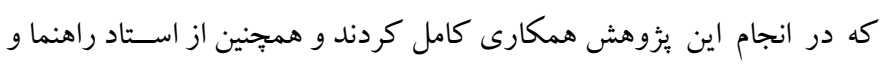
مشاور اين يُزوهش، صميمانه سياسگز اريم. تضـاد منافع: اين يزوهش بدون حمايت مالى سـازمان خاصى صورت گرفته است و نتايج آن براى نويسند گان، هيج گونه تضاد منافعى نداشته است.
درماها در حيطه اختلال اضـطر اب اجتماعى براى دانش آموزان اسـتفاده شود.

تشكر و قدردانى: اين بزوهش بر گرفته از رسـاله دكتراى خانم رمينا روحى

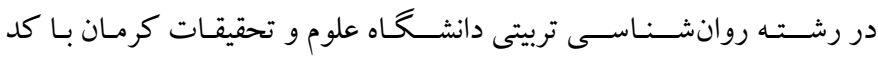

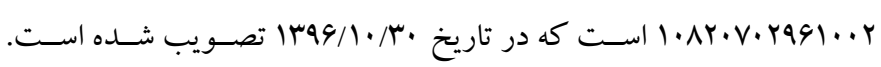

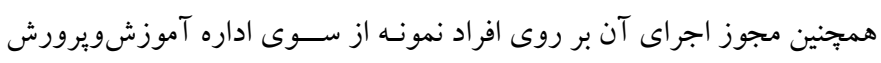




\section{References}

1. Williams JB, Spitzer RL. Research diagnostic criteria and DSM-III: an annotated comparison. Arch Gen Psychiatry. 1982; 39(11): 1283-1289. [Link]

2. Molavi P, Mikaeili N, Rahimi N, Mehri S. The effectiveness of acceptance and commitment therapy based on reducing anxiety and depression in students with social phobia. Journal of Ardabil University of Medical Sciences. 2014; 14(4): 412-423. [Persian]. [Link]

3. Arch JJ, Landy LN, Brown KW. Predictors and moderators of biopsychological social stress responses following brief self-compassion meditation training. Psychoneuroendocrinology. 2016; 69: 35-40. [Link]

4. Duval ER, Javanbakht A, Liberzon I. Neural circuits in anxiety and stress disorders: a focused review. Ther Clin Risk Manag. 2015; 11: 115-126. [Link]

5. Priestley J. Acceptance and commitment therapy for public speaking anxiety: a case series study of effects on self-reported, implicit, imaginal, and in-vivo outcomes [Doctoral thesis]. [Lincoln, England]: University of Lincoln; 2016. [Link]

6. Anderson ER, Hope DA. The relationship among social phobia, objective and perceived physiological reactivity, and anxiety sensitivity in an adolescent population. J Anxiety Disord. 2009;23(1):18-26. [Link]

7. Asnaani A, Aderka IM, Marques L, Simon N, Robinaugh DJ, Hofmann SG. The structure of feared social situations among race-ethnic minorities and Whites with social anxiety disorder in the United States. Transcult Psychiatry. 2015; 52(6): 791-807. [Link]

8. Goetz JL, Keltner D, Simon-Thomas E. Compassion: an evolutionary analysis and empirical review. Psychol Bull. 2010; 136(3): 351-374. [Link]

9. Neff KD. The self-compassion scale is a valid and theoretically coherent measure of self-compassion. Mindfulness. 2016; 7(1): 264-274. [Link]

10. Raes F. Rumination and worry as mediators of the relationship between self-compassion and depression and anxiety. Pers Individ Dif. 2010; 48(6): 757-761. [Link]

11. Leaviss J, Uttley L. Psychotherapeutic benefits of compassion-focused therapy: an early systematic review. Psychol Med. 2015; 45(5): 927-945. [Link]

12. Rutherford HJV, Goldberg B, Luyten P, Bridgett DJ, Mayes LC. Parental reflective functioning is associated with tolerance of infant distress but not general distress: Evidence for a specific relationship using a simulated baby paradigm. Infant Behav Dev. 2013; 36(4): 635-641. [Link]

13. Kozak AT, Fought A. Beyond alcohol and drug addiction. Does the negative trait of low distress tolerance have an association with overeating? Appetite. 2011; 57(3): 578-581. [Link]

14. Simons JS, Gaher RM. The distress tolerance scale: development and validation of a self-report measure. Motiv Emot. 2005; 29(2): 83-102. [Link]

15. Kelishadi F, Yazdkhasti F. Impact of perception of parental rejection-acceptance and control on moral intelligence and distress tolerance. Strategy for Culture. 2016; 9(33): 155-169. [Persian]. [Link]

16. Sheydayi Aghdam S, Shamseddini Lory S, Abassi S, Yosefi S, Abdollahi S, Moradi Joo M. The effectiveness of treatment based on acceptance and commitment in reducing distress and inefficient attitudes in patients with MS. Thoughts and Behavior in Clinical Psychology. 2015; 9(34): 57-66. [Persian]. [Link]

17. Hosein Esfand Zad A, Shams G, Pasha Meysami A, Erfan A. The role of mindfulness, emotion regulation, distress tolerance and interpersonal effectiveness in predicting obsessive-compulsive symptoms. Iranian Journal of Psychiatry and Clinical Psychology. 2017; 22(4): 270-283. [Persian]. [Link]

18. Havaiy A, Kazemi H, Habibollahi A, Izadikhah Z. The effect of emotion regulation on the amount of tension tolerance and emotion regulation difficulties in women with tension-type headaches. Journal of Shahid Sadoughi University of Medical Sciences. 2017; 24(10): 840-851. [Persian]. [Link]

19. Karami J, Heidarisharaf P, Shafeei B. Relationship between emotion regulation strategies and emotional intelligence with social phobia in the blind and deaf students. Exceptional Education. 2015; 1(129): 5-14. [Persian]. [Link]

20. Garnefski N, Kraaij V. The cognitive emotion regulation questionnaire. Eur J Psychol Assess. 2007; 23(3): 141-149. [Link]

21. Mohammadi L, Salehzade Abarghoei M, Nasirian M. Effectiveness of acceptance and commitment therapy on cognitive emotion regulation in men under methadone treatment. Journal of Shahid Sadoughi University of Medical Sciences. 2015; 23(9): 853861. [Persian]. [Link]

22. Hayes SC, Luoma JB, Bond FW, Masuda A, Lillis J. Acceptance and commitment therapy: model, processes and outcomes. Behav Res Ther. 2006; 44(1): 1-25. [Link] 
23. Forman EM, Herbert JD. New directions in cognitive behavior therapy: acceptance-based therapies. In: O'Donohue WT, Fisher JE, editors. General principles and empirically supported techniques of cognitive behavior therapy. Hoboken, NJ, US: John Wiley \& Sons Inc; 2009, pp: 77-101. [Link]

24. Connor KM, Davidson JR, Churchill LE, Sherwood A, Foa E, Weisler RH. Psychometric properties of the social phobia inventory (SPIN). New self-rating scale. Br J Psychiatry. 2000; 176: 379-386. [Link]

25. Hassanvand Amouzadeh M. Validity and reliability of social phobia inventory in students with social anxiety. Journal of Mazandaran University of Medical Sciences. 2016; 26(139): 166-177. [Persian]. [Link]

26. Azizi A, Mirzaei A, Shams J. Correlation between distress tolerance and emotional regulation with students smoking dependence. Hakim Health Systems Research Journal. 2010; 13(1): 11-18. [Persian]. [Link]

27. Noorbala F, Borjali A, Noorbala AA. The interaction effect between "Self-Compassion" and "Rumination" of depressed patients in "Compassion Focused Therapy". Daneshvar Medicine. 2013; 20(104): 7784. [Persian]. [Link]

28. Hasani J. The psychometric properties of the cognitive emotion regulation questionnaire (CERQ).
Journal of Clinical Psychology. 2010; 2(3): 73-84. [Persian]. [Link]

29. Hoffmann D, Halsboe L, Eilenberg T, Jensen JS, Frostholm L. A pilot study of processes of change in group-based acceptance and commitment therapy for health anxiety. J Contextual Behav Sci. 2014; 3(3): 189-195. [Link]

30. Eifert GH, Forsyth JP, Arch J, Espejo E, Keller M, Langer D. Acceptance and commitment therapy for anxiety disorders: three case studies exemplifying a unified treatment protocol. Cogn Behav Pract. 2009; 16(4): 368-385. [Link]

31. Faytout M, Tignol J, Swendsen J, Grabot D, Aouizerate B, Lépine JP. Social phobia, fear of negative evaluation and harm avoidance. Eur Psychiatry. 2007; 22(2): 75-79. [Link]

32. Keough ME, Riccardi CJ, Timpano KR, Mitchell MA, Schmidt NB. Anxiety symptomatology: the association with distress tolerance and anxiety sensitivity. Behav Ther. 2010; 41(4): 567-574. [Link]

33. Freeth M, Bullock T, Milne E. The distribution of and relationship between autistic traits and social anxiety in a UK student population. Autism. 2013; 17(5): 571581. [Link] 